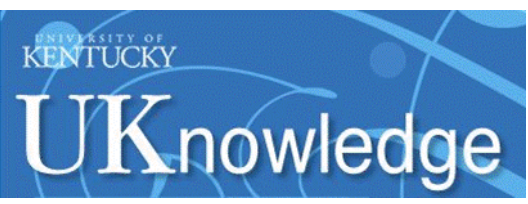

Kentucky Law Journal

Volume 100 | Issue 3

Article 3

2012

\title{
Tackling Shareholder Short-Termism and Managerial Myopia
}

Emeka Duruigbo

Texas Southern University

Follow this and additional works at: https://uknowledge.uky.edu/klj

Part of the Business Organizations Law Commons

Right click to open a feedback form in a new tab to let us know how this document benefits you.

\section{Recommended Citation}

Duruigbo, Emeka (2012) "Tackling Shareholder Short-Termism and Managerial Myopia," Kentucky Law Journal: Vol. 100: Iss. 3, Article 3.

Available at: https://uknowledge.uky.edu/klj/vol100/iss3/3

This Article is brought to you for free and open access by the Law Journals at UKnowledge. It has been accepted for inclusion in Kentucky Law Journal by an authorized editor of UKnowledge. For more information, please contact UKnowledge@lsv.uky.edu. 


\title{
Tackling Shareholder Short-Termism and Managerial Myopia
}

\author{
Emeka Duruigbo
}

\section{INTRODUCTION}

ChorT-Termism denotes the phenomenon by which some corporate

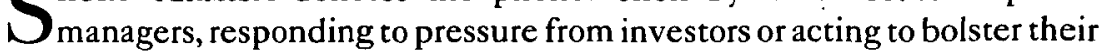
own position, advert their attention and exert their energies to achieving short-term profitability, virtually eschewing longer-term considerations. ${ }^{2}$ It is important to emphasize at the outset that short-termism is not coterminous with holding stocks for short periods by investors. Shorttermism refers to the investment approach in which investors "push managers to invest in short-term projects in order to keep earnings high. In this sense, investors who behave in a short-termistic manner may well have long holding periods, provided managers satisfy the investors' need for high earnings period by period." 3 Short-termism promotes a tendency to overvalue short-term rewards, invariably leading to an undervaluation of long term consequences. ${ }^{4}$ Indeed, some market observers and legal commentators link the collapse, a few years ago, of giant energy company Enron and some fabled financial firms to investors acting like traders and influencing corporate managers to make policy decisions based on quarterly earnings statements. ${ }^{5}$ One analyst dissects the malaise in this

I Associate Professor of Law, Thurgood Marshall School of Law, Texas Southern University. Special thanks to Mitch Crusto, Erik Gerding, Francine Lipman, Mark Matthews and participants in Conferences at Arizona State University, Southern Methodist University (John Mercer Langston Workshop), Texas Southern University and the Southeastern Association of Law Schools (New Scholars Workshop) for providing helpful discussion and comments on earlier drafts. Many thanks to Thurgood Marshall School of Law for generous summer research funding and to Janelle Marshall, Samuel Sarfo, Shamia Cottrell and Iveoma Okparaeke for outstanding research assistance.

2 Austl. Gov't Corps. \& Mkt. Advisory Comm., The Social Responsibility of CorpoRATIONS REPORT 2 I (2006).

$3 \emptyset$ yvind Bøhren, Richard Priestley \& Bernt Arne Ødegaard, Investor Short-Termism and Firm Value I n. I (Aug. 28, 2009) (unpublished manuscript), available at http://finance. bi.no/_bernt/wps/ownership_duration/duration_aug_2009.pdf.

4 See Kevin J. Laverty, Managerial Myopia or Systemic Short-termism?: The Importance of Managerial Systems in Valuing the Long Term, 42 MGMT. Decision 949, 950 (2004) (discussing the phenomenon of organizations overvaluing short-term rewards and undervaluing long-term consequences).

5 See, e.g., Jill E. Fisch, Measuring Efficiency in Corporate Law: The Role of Shareholder Pri- 
manner: "Financial analysts fixate on quarterly earnings at the expense of fundamental research. Corporate executives, in turn, point to the behavior of the investment community to rationalize their own obsession with earnings. 'Short-termism' is the disease; earnings and tracking error are the carriers." 6

The issue of short-termism has acquired sufficient currency that it has become easy, if not convenient, to attribute a host of corporate actions to the dominance of short-term thinking. One of the alleged culprits in

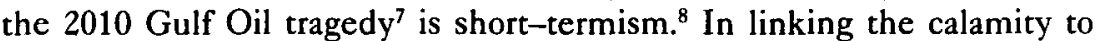
short-termism and stock trading, one commentator states that the current system of organizing and managing public companies, with its focus on quarterly earnings and shareholder primacy orchestrated the problem. ${ }^{9}$ The

macy, 31 J. CoRp. L. 637, 673 (2006) (discussing the role of short-termism in the collapse of fabled energy giant, Enron); Leo E. Strine, Jr., Toward A True Corporate Republic: A Traditionalist Response to Bebchuk's Solution for Improving Corporate America, i I9 HARv. L. REv. 1759, 1772-73 (2006) (explaining the short-term approach to investment); William W. Bratton, Enron and the Dark Side of Shareholder Value, 76 TUL. L. Rev. 1275,1283 (2002) (explaining the collapse of Enron in terms of risk-prone policy, short-term decision-making).

6 Alfred Rappaport, The Economics of Short-Term Performance Obsession, 6I Fin. AnaLYsTs J. 65, 65 (2005); Martin Lipton, Theodore N. Mirvis \& Jay W. Lorsch, The Proposed "Shareholder Bill of Rights of 2009", The Harv. L. SCH. F. ON CORP. Governance \& Fin. Reg. (May I2, 2009, 4:56 PM), http://blogs.law.harvard.edu/corpgov/2009/05/12/the-proposed$\% \mathrm{E} 2 \% 80 \% 9$ Cshareholder-bill-of-rights-act-of-2009\% E2\%80\%9D/ (stating that "[s]horttermism is a disease that infects American business and distorts management and boardroom judgment" although its origin can be traced outside the boardroom to "the trading rooms of the hedge funds and professional institutional investment managers who control more than $75 \%$ of the shares of most major companies").

7 The Deep Horizon disaster of April 20 Io claimed the lives of eleven oil platform workers and virtually engulfed the United States operations of international energy giant, BP Plc. The tragedy perhaps inexorably altered the health, lives, livelihoods, and culture of millions of people, plants, and animals in several states. See Adam Thomson, Gulf Fishermen Put BP on the Hook for Losses, Fin. Times, Aug. 12, 2010, http://www.ft.com/intl/cms/s/76563048-a6561 I df-8; Enjoli Francis, Diverse Community of the Bayou Laments Life After Oil Leak, ABC WorLD NEws, July 13, 2010 , http://abcnews.go.com/WN/world-news-diane-sawyer-heads-bayoucajun-territory/story? id $=11153282 \&$ page $=1$.

8 Tim Lynch, Two Spills Can Teach Us Lessons, Tallahassee Democrat, July 30, 2010 ("This damage is being incurred because of short-term profit-induced inadequate planning and implementation on the part of BP, its consultants and federal regulators."); see also Steve Richards, I Hope the Slovenians Beat Us, INDEP. (U.K.), June 22, 2010, http://www.independent. co.uk/opinion/commentators/steve-richards/steve-richards-i-hope-the-slovenians-beatus-2006897.html (referencing "the short-term, cost-cutting calculations from BP that led to an environmental crisis in the US").

9 Jay Coen Gilbert, A Solution to the BP Problem: Changing the Rules of the Game, Forbes (June II, 2010, 3:1 I PM), http://blogs.forbes.com/csr/2010/o6/II/273/; see also Stephen P. Berzon, et al., Conference Transcript, How Law Constructs Wealth Patterns, 15 Geo. J. ON Poverty L. \& Pol'y 509, 521 (2009) [hereinafter Greenfield, Wealth Patterns] (Greenfield, Kent) (drawing a link between short-termism and shareholder primacy). For an overview of the debate about shareholder primacy and the protection of the interests of other stakeholders and third parties, including in relation to environmental protection, see Ian B. Lee, Efficiency 
commentator adds that every segment of the corporate chain, including directors, senior officers and line managers, is burdened by enormous pressure to generate short-term profits. ${ }^{10} \mathrm{BP}$, the international energy giant at the center of the Deep Horizon disaster, is not new to accusations of short-termism. In 2008, two authors of a law review article concluded from a collection of past industrial accidents ${ }^{11}$ that BP. was enmeshed in the phenomenon of short-termism. ${ }^{12}$ The authors stated that the company "has not resolved its central design challenge: How to structure internal decision-making to give priority to long-term environmental sustainability instead of short-term cost-cutting." 13

Recently also, Harvard Business School Professor Bill George undertook a brief exploration of the issue of short-termism in the biotechnology industry. ${ }^{14} \mathrm{He}$ examined a recent corporate battle that exemplifies the

and Ethics in the Debate About Shareholder Primacy, 3 I DeL. J. Corp. L. 533 (2006). For a strong defense of shareholder primacy which rejects the arguments that shareholders do not own the firm and lays a foundation for the allocation of power in a corporation in favor of shareholders, see Julian Velasco, Shareholder Owenership and Primacy, 2010 U. ILL. L. REv. 897. See generally Lynn A. Stout, Bad and Not-so-Bad Arguments for Shareholder Primacy, 75 S. CAL. L. Rev. 1189, I I 90-207 (2002) (outlining the pros and cons of shareholder primacy).

Io Gilbert, supra note 9.

I I See T.J. Aulds, Thousands Line up to Join BP Lawsuit, Daily News (Galveston County, Tex.), Aug. 5, 2010, http://galvestondailynews.com/story/167178; Sheila McNulty \& Anna Fifiel, BP to Pay Record Fine over Texas City, Fin. Times, Aug. 12, 2010, http://www.ft.com/ intl/cms/s/o/e878cca6-a63f-1 1df-8767-00144feabdco.html; Jad Mouawad, For New Chief, BP's Problems Range from Rusted Pipes to a Tarmished Image, N.Y. TIMEs, May 4, 2007, at $\mathrm{C}_{3}$ (quoting Congressman John Dingell); Steven Mufson, Probe Finds BP Cost-Cutting Contributed to Texas Refinery Blast, WASH. Post, Oct. 3I, 2006, at Dor; Michael Peel \& Fiona Harvey, Lawsuits Threaten BP over Air Pollution, Fin. Times, Aug. 9, 20 Io, http:/www.ft.com/intl/cms/ s/o/o676bbf6-a3ce-I I df-9e3a-0o I 44feabdco.html\#axzz I hhWGMm3W.

12 Marjorie Kelly \& Allen White, Corporate Design: The Missing Organizational and Public Policy Issue of Our Time, 42 New ENG. L. Rev. 761, 763-64 (2008).

I3 Id. at 764. BP has been charged in past environmental and safery incidents with excessive cost-saving. According to The Economist:

$$
\begin{aligned}
& \text { In } 2005 \text { an explosion at its rundown Texas City refinery killed } 15 \text { workers. It } \\
& \text { received } 97 \% \text { of all operational safety and health citations for "wilful" [sic] and } \\
& \text { "egregiously wilful" [sic] breaches at American oil refineries between June } 2007 \\
& \text { and February } 2010-\text { a remarkable share even allowing for close scrutiny after } \\
& \text { Texas City. } \\
& \text { Some in the American oil industry think this reflects a poor corporate culcure } \\
& \text { at BP, in which personal advancement has depended more on cutting costs than } \\
& \text { on technical proficiency. }
\end{aligned}
$$

The Oil Well and the Damage Done: BP Counts the Political and Financial Cost of Deepwater Horizon, Economist, June 17, 2010, http://www.economist.com/node/16381032; see also Colin L Leci, Letter to the Editor, Don't. Blame BP Engineers, Dally Telegraph (London), Jan. 22, 2007, at 4 . It should be noted that cost-cutting is not necessarily illegitimate, as good managers always seck to maximize their resources. However, it could also be interpreted as a response to short-term pressure.

14 Bill George, Another Viev: Can Biotech Survive Icahn?, DEALBook (June 3, 2010, 9:15 AM), http://dealbook.blogs.nytimes.com/2010/o6/o3/another-view-can-biotech-survive- 
tension between investors pushing for the maximization of short-term shareholder value and an industry largely dependent on substantial investments and significant blocks of time for the creation of long-term shareholder value. He concluded by wondering about the survivability of the biotechnology industry that relies on long-term investment to develop products that are critical to society. ${ }^{15}$ This observation captures the sentiment of many opponents of short-termism who note that the future well-being of many investors, corporations, overall economy and society at large is in jeopardy if investors with a near-term horizon, especially hedge funds, enjoy a domineering influence in determining the direction taken by a corporation. ${ }^{16}$ One observer contends that an excessive focus on the short-term engenders misallocation of assets by corporate managers, leads to harmful volatility in the financial markets and imposes a burden on society to channel productive resources into repairing environmental and social damage occasioned by unbridled quest for profits. ${ }^{17}$ Skeptics, however, dismiss the concerns, insisting that the notion of pervasive shortterm investing is a figment of opponents' imagination. Moreover, shortterm investors provide needed liquidity and stability to the markets.

This article examines the ongoing debate about the import of the various investment horizons and presents a critical appraisal of three prominent proposals for addressing shareholder short-termism and encouraging long-term investment, namely securities transaction tax, capital gains tax reform, and loyalty dividends. ${ }^{18}$ It acknowledges their strengths but also

icahn/.

$15 I d$.

i6 R. Franklin Balotti et al., Meetings of Stockholders $\$ 5^{-16}$ to -I 7 (discussing the theory propounded by some commentators that the short-termism and activism exhibited by certain investors present enormous threat to the economic health of corporations and the country); Leo E. Strine, Jr., One Fundamental Corporate Governance Question We Face: Can Corporations Be Managed for the Long Term Unless Their Powerful Electorates Also Act and Think Long Term?, 66 Bus. LAw. 1, 12 (2010) [hereinafter Strine, Governance Question] ("[I]t is increasingly the case that the agenda setters in corporate policy discussions are highly leveraged hedge funds, with no long-term commitment to the corporations in which they invest.").

17 Steve Lydenberg, Building the Case for Long-Term Investing in Stock Markets: Breaking Free from the Short-Term Measurement Dilemma, in Finance fOr a BetTer World: The Shift Toward Sustainability I68 (Henri-Claude de Bettignies \& François Lépineux eds., 2009); see also Frederick Beale \& Mario Fernando, Short-termism and Genuineness in Environmental Initiatives: A Comparative Case Study of Teo Oil Companies, 27 Eur. MGMT. J. 26, 27 (2009) ("[T] he short-term focus on the share price has been counterproductive for long run economic growth as well as social cohesion and environmental sustainability."); Broc Romanek, Can We Overcome Short-Termism?, TheCorporateCounsel.net (Sept. 22, 2009, 7:0o AM), http://www. thecorporatecounsel.net/Blog/2009/og/can-we-overcome-short-termism.html ("Short-term traders have little reason to care about long-term corporate performance - so are unlikely to exercise a positive role in promoting corporate policies and can lead to market failures, social and environmental degradation.").

I 8 See, e.g., Katharine Jackson, Pension-Funding the Future: Encouraging the Sustainable and Socially Responsible Development of Securities Markets in Sub-Saharan Africa, 44 INT'L Law. 791, 
notes their weaknesses. For instance, because of the Wall Street Rule and innovative avoidance vehicles, it is doubtful that even a high percentage tax on capital gains or sale of securities will eliminate short-termism. ${ }^{19}$ The adequacy of the incentives provided by loyalty dividends both in terms of financial rewards and shareholder empowerment appears questionable to affect short-term investor behavior. In sum, these demerits caution against creating a situation in which the remedy becomes worse than the malady.

Moreover, the management side of the equation deserves equal, if not greater, engagement in seeking to craft solutions to the problem. ${ }^{20}$ Managerial myopia, independent of investor short-termism, may be a contested fact, but there is sufficient reason to believe it exists. ${ }^{21}$ What is needed is a framework that dissuades managers from their independent short-termism and protects them from pressure from short-horizon investors. In that connection, this article proposes the adoption of longterm shareholder primacy as the guiding norm of corporate behavior. Thus, managerial conduct and board supervision will be undertaken within the rubric of this norm. The legal recognition and corporate internalization of such a norm will provide a valuable underpinning for such reform proposals as executive compensation reform and expansion of director fiduciary duties that serve as dissuasion and insulation tools respectively.

The rest of the article proceeds in seven parts. Part I presents a synopsis of the short-termism phenomenon, and the debate it has generated.

814 (2010) (stating that one of the recommendations for dealing with short-termism is "regulation of shareholder remuneration (dividend) programs so as to align them with long-term interests"); Bus. \& Soc'y Program, Aspen Inst, Overcoming Short-Termism: A Call for a More Responsible Approach To Investment And Business Management 3 (2009) [hereinafter ASPEN INST.], available at http://www.aspeninstitute.org/sites/default/files/content/images/ Overcoming\%20Short-termism\%20AspenCVSG\%2015dec09.pdf (proposing the imposition of a securities transaction tax and reform of capital gains tax law to discourage short-term . trading).

19 The Wall Street Rule refers to the practice by stockholders of selling their stock at any point, especially when they are dissatisfied with the management of the corporation. See Barnali Choudhury, Serving Two Masters: Incorporating Social Responsibility into the Corporate Paradigm, I I U. PA. J. Bus. L. 63 I, 670 (2009); Carol Goforth, Proxy Reform as a Means of Increasing Shareholder Participation in Corporate Governance: Too Little, But Not Too Late, 43 AM. U. L. REv. 379, 406 (1994) ("The Wall Street Rule holds that shareholders who are dissatisfied with management decisions can 'vote with their feet' by selling their shares and finding a different enterprise in which to invest.").

20 Unless otherwise noted, this article uses the terms "management" or "managers" as shorthand ways of referring "collectively to the corporation's board of directors and senior officers." See David Millon, Theories of the Corporation, 1990 Duke L.J. 20 I, 201 n. 1.

2 I Marcel Kahan \& Edward B. Rock, Hedge Funds in Corporate Governance and Corporate Control, 155 U. PA. L. Rev. 102 I, 1088 (2007) [hereinafter Kahan \& Rock, Hedge Funds] ("A plausible argument can be made that it is managers, not just markets, that suffer from myopia these days. Many CEOs are close to retirement age and, even among younger CEOs, turnover is high. Executives' stock options continually vest and are exercised or hedged, if only to diversify their portfolio. Bonuses are often based on short-term performance goals."). 
Parts II, III and IV evaluate three proposals that have been advanced for addressing shareholder short-termism, discussing their advantages and disadvantages. Part $V$ notes that any effort at addressing investor myopia needs to be coupled with a strong effort to address managerial myopia. While it may be the case that managers are pressured into short-term thinking by shareholders, it is also true that managers can be independently myopic. The coupling may be undertaken within the rubric of a corporate norm of long-term shareholder primacy discussed in Part VI. Part VII is the Conclusion.

\section{The Short-Termism Phenomenon}

\section{A. The Concept of Short-Termism}

Short-termism has been defined as "a preference for actions in the near-term without due consideration of the long term consequences." 22 The Business Roundtable describes it as "the excessive focus of some corporate leaders, investors, and analysts on short-term, quarterly earnings and a lack of attention to the strategy, fundamentals, and conventional approaches to long-term value creation." 23 Short-termism may exist both in investing and in corporate management; thus, the focus of this article is shareholder short-termism and the concomitant corporate myopia. ${ }^{24}$ Shareholder short-termism is said to manifest in two major ways, namely 'pressure' and 'walk.' Some shareholders' penchant for quick returns on investment puts pressure on corporate managers to be fixated on shortterm results, even at the expense of long-run performance. ${ }^{25}$ Besides,

22 Alison Atherton et al., Inst. for Sustainable Futures, Gauses of ShortTERMISM IN THE FINANCE SECTOR 2 (2007), available at http://www.isf.uts.edu.au/publications/ athertọn2007causesofshorttermism.pdf.

23 Dean Krehmeyer et al., CFA Centre for Fin. Market Integrity \& Bus. Roundtable Inst. for Corp. Ethics, Breaking the Short-Term Cycle: Discussion and Recommendations on How Corporate Leaders, Asset Managers, Investors, and Analysts can Refocus on Long-Term VAlue 3 (2006).

24 Theresa A. Gabaldon, Corporate Conscience and the White Man's Burden, 70 Geo. WASH. L. Rev. 944, 949 (2002); see Bernard S. Black, Agents Watching Agents: The Promise of Institutional Investor Voice, 39 UCLA L. Rev. 81 I, 865 ( 1992) [hereinafter Black, Watching Agents] (discussing on managerial myopia and its motivating factors); see also Bratton, supra note 5, at 1327-28 (discussing the myopia of Enron's managers); M.P. Narayanan, Managerial Incentives for Short-Term Results, 40 J. FiN. 1469, I 469-70 ( 1985 ) (attributing managerial myopia to reputational incentives). See generally Eduard Gracia, Corporate Short-Term Thinking and the Winner-Take-All Market (Deloitte Consulting, Working Paper, 2003), available at http:/papers.ssrn.com/sol3/papers. cfm?abstract_id=445260 (attributing managerial myopia to a "winner-take-all" mentality).

25 See Patrick Bolton et al., Pay for Short-Term Performance: Executive Compensation in Speculative Markets, 30 J. CoRP. L. 72 I, 725 (2005); Lucian Arye Bebchuk \& Lars A. Stole, Do Short-Term Objectives Lead to Under- or Overinvestment in Long-Term Projects?, 48 J. Fin. 719, 719-20 (1993); Jeremy C. Stein, Takeover Threats and Managerial Myopia, 96 J. PoL. Econ. 61, 
shareholders have a tendency to prefer "exit" to "voice."26 That is, they would rather sell their stock if dissatisfied with corporate management

61-62 ( I 988); Bøhren, Priestley \& Ødegaard, supra note 3, at 14 ("[W] hen short-termist investors influence the firm over extended periods, they pressure managers into myopic behavior which reduces firm value. .. [As] managers try to maintain high short-term earnings at the expense of profitable long-term projects.").

26 Louis Lowenstein, What's Wrong with Wall Street: Short-Term Gain and the Absentee Shareholder 91-92 (1988); see also J.H.H. Weiler, The Transformation of Europe, 100 YALE L.J. 2403, 24II (1991) ("Exit is the mechanism of organizational abandonment in the face of unsatisfactory performance. Voice is the mechanism of intraorganizational correction and recuperation."). The exit-voice formulation was initially made by the economist Albert Hirschman. Albert O. Hirschman, Exit, Voice, and Loyalty: Responses to Decline in Firms, Organizations, and States 30 (1970) ("Voice is . . defined as any attempt at all to change, rather than to escape from, an objectionable state of affairs, whether through individual or collective petition to the management directly in charge, through appeal to a higher authority with the intention of forcing a change in management, or through various types of actions and protests, including those that are meant to mobilize public opinion."). A slightly different articulation of the concepts presents exit and voice as "variants of the same phenomenon," rather than as alternate phenomena. See Sarah Maxwell, The Price Is Wrong: Understanding What Makes a Price Seem Fair and the True Cost of Unfair Pricing 76 (2008) ("Having a choice gives consumers voice by allowing them to express their opinion. They are not being forced to buy at one pre-set price or do without."); Andrew E. Taslitz, Judging Jena's D.A.: The Prosecutor and Racial Esteem, 44 HaRv. C.R.-C.L. L. Rev. 393, 428-29 (2009) ("A buyer having a real choice among a range of viable alternatives and the freedom to exit one potential deal for a better one gives the buyer some measure of voice."). 
than stay in and affect direction of corporate policy. ${ }^{27}$ Ultimately, this works against good corporate performance. ${ }^{28}$

Short-termism is not limited to any particular section of the investor class, although the investors most often associated with it are hedge funds. ${ }^{29}$

27 There are similar reactions by employees. Hilary K. Josephs, Measuring Progress Under China's Labor Law: Goals, Processes, Outcomes, 30 Comp. Lab. L. \& Pol'y J. 373, 393 (2009) ("There are indications that workers will resort to 'exit' rather than 'voice' if confrontational tactics do not look promising."). There are similar reactions within the lawyer-client relationship. William L.F. Felstiner \& Austin Sarat, Enactments of Power: Negotiating Reality and Responsibility in Lawer-Client Interactions, 77 CORNeLL L. Rev. I447, 1464 (1992) ("In the face of lawyers' insistence that they accommodate themselves to the reality of what the law allows, clients generally persist, at least initially, in expounding their needs, explaining their notions of justice, or reiterating their objectives. But rarely do they insist that their lawyer make a particular demand, argue a particular position, or even endorse their view. Where dissatisfaction is great, the usual client response is exit rather than voice."); $c f$. David B. Wilkins, Team of Rivals? Toward a New Model of the Corporate Attormey-Client Relationship, 78 Fordham L. Rev. 2067, 207 I (2010) (discussing how some clients and attorneys utilize voice in their relationship, although the threat of exit remains in the vicinity).

28 Lowenstein, supra note 26, at 91-92. According to Hirschman,

\begin{abstract}
[S]ituations in which exit is the predominant reaction to decline while voice might be more efficacious in arresting it can also be observed in the sphere of private business enterprise. The relation between corporate management and the stockholders is a case in point. When the management of a corporation deteriorates the first reaction of the best-informed stockholders is to look around for the stock of better-managed companies. In thus orienting themselves toward exit, rather than toward voice, investors are said to follow the Wall Street rule that "if you do not like the management you should sell your stock." According to a well-known manual this rule "results in perpetuating bad management and bad policies."
\end{abstract}

Hirschman, supra note 26 , at 46 . The problem is not simply that shareholders are exiting. The problem is that often the type of shareholder that exits quickly is the one that can make a real difference because it is well-informed and is likely to have the motivation and determination to mount a serious fight for change if the alternative of investing elsewhere was not readily present. Thus, the real tragedy is that those shareholders who are most sophisticated and "who, therefore, are those who would be the most active, reliable, and creative agents of voice are for that very reason are those who are apparently likely to exit first in case of deterioration." Id. at 47; see also Jean Tirole, Corporate Governance, 69 Econometrica I, 5 (2001) (stating that the exercise of voice by shareholders and other constituents make a firm more efficient because, among other things, "active monitors may turn down a negative NPV [net present value] project sponsored by management, force the divestiture of a noncore division, or remove management altogether.")

29 See Kevin J. Coco, Empty Manipulation: Bankruptcy Procedure Rule 2019 and Oenership Disclosure in Chapter II Cases, 2008 Colum. Bus. L. Rev. 610, 619; Jennifer Ralph Oppold, The Changing Landscape of Hedge Fund Regulation: Current Concerns and a Principle-Based Approach, Io U. PA. J. Bus. \& EMP. L. 833, 869-70 (2008); see also Faith Stevelman, Going Private at the Intersection of the Market and the Law, 62 Bus. LAw. 775, 902 (2007) ("[I]nstitutional investors (especially hedge funds) are increasingly positioning themselves to respond to short term market price changes, as intensified by the role of arbitrageurs in corporate transactions."). However, there is not a clear definition of hedge funds. Oppold, supra, at 833-34 ("The term 'hedge fund' does not have a single accepted definition although it is generally understood to be an unregistered pooled investment vehicle that invests in a broad range of securities, with a fee structure that typically compensates the fund advisor based upon a combination of assets under management and a percent of capital appreciation."). 
This is intuitive as the investment strategy of hedge funds, including speculation, naturally comport with buying and holding stock for short periods of time. ${ }^{30}$ However, the hedge fund industry is not alone in this practice. "Speculation is found not merely in the operation of hedge funds and in derivatives trading, but also in a large population of high-turnover portfolio managers ready to jump in and out of the market." ${ }^{31}$ Some of the pension funds that traditionally invest with a long-term horizon have also joined the bandwagon, committing some of their assets to high turnover managers or hedge funds. ${ }^{32}$ Also involved in the speculation excursion are high turnover individuals and day traders. ${ }^{33}$

Analysts also view major institutional investors as contributing to shorttermism by creating a disconnect between asset owners and asset managers. One of the areas in which this misalignment manifests is in investment time horizon. ${ }^{34}$ Because many of these institutions engage in quarterly evaluation of their fund managers' performance, the fund managers have little option than to deploy their efforts into delivery of short-term returns, often necessitating putting pressure on investee companies to focus on maximizing near-term profits. ${ }^{35}$ Another area in which interests are not

30 Matteo Tonello, The Conference Bd., Revisiting Stock Market Short-Termism 7 (2006) ("[S]tock investment speculation is a major cause of market short-termism. Some blamed the rise of the hedge fund industry, which is speculative by definition."); Kahan $\&$ Rock, Hedge Funds, supra note $2 \mathrm{I}$, at 1087 ("Short-termism . . presents the potentially most important, most controversial, most ambiguous, and most complex problem associated with hedge fund activism."); see also Catherine L. Pollina, Bursting the Speculation Buying Bubble: Modifications to the Capital Gains Provision and the 1031 Exchange Rule, 3 Hastings Bus. L.J. 27 I, 273 (2007) (defining speculative buying as the purchase of an asset "based on the speculation of appreciation of future value instead of using an analysis of the property's income fundamentals."); James R. Repetti, The Use of Tax Law to Stabilize the Stock Market: The Efficacy of Holding Period Requirements, 8 VA. TAx REv. 591, 596 (1989) [hereinafter Repetti, Tax Law] ("[S] peculation is the purchase of an item with a view to selling it at a higher price within a short period of time.").

31 Tonello, supra note 30 , at 7 .

32 Id.; see also Greenfield, Wealth Patterns, supra noce 9, at 521.

33 Tonello, supra note 30, at 7 ("Sitting and waiting for long-term growth is simply not contemplated in the strategies of those investors who are willing to take huge risks to enjoy multiple-digit capital appreciation.").

34 See Li Jin, How Does Investor Short-Termism Affect Mutual Fund Manager Short-termism 2-3 (April 2005) (unpublished manuscript), available at http:/www.hbs.edu/units/am/pdf/ short_termism_paper_050414.pdf ("[F]und managers facing higher short-term performance pressure are more focused on short horizon investments ... [and] fund manager's short investment horizons are caused by their investors' short horizons, but not the other way round.").

35 Simon Wong, Tackling the Root Causes of Shareholder Passivity and Short-Termism, Harv. L. Sch. F. ON Corp. Governance \& Fin. Reg. (Jan. 31, 2010, 9:41 AM), http://blogs.law. harvard. edu/corpgov/2010/01/31/tackling-the-root-causes-of-shareholder-passivity-and-shorttermism/; $c f$. Lydenberg, supra note I 7 , at 170 (explaining the benefits of long-term investment). 
aligned is in asset manager compensation..$^{36} \mathrm{~A}$ number of pension funds maintain a fee structure that involves non-payment of management fees, which could be assessed as a percentage of assets under management, in exchange for a permission to lend the shares and earn a financial return as a result. ${ }^{37}$ The attendant problem is that the severely conflicted asset manager has virtually no incentive to maximize the value of the portfolio. ${ }^{38}$ For example, waging a successful proxy contest might require that the lent shares be recalled for the purpose of voting but the fund manager may be reluctant to do so because of the revenue loss that such recall would occasion. $^{39}$

\section{B. The Short Term - Long Term Debate}

1. Historical Overview.-For approximately three decades now, academic commentators, corporate lawyers, the investment community, and other interested parties have been commenting on the short-termism phenomenon. ${ }^{40}$ While in the past, concerns about short-termism were easily dismissed as ideologically motivated, there is a resurgence of interest in the subject from quarters that cut across the ideological divide. ${ }^{41}$ This priority of attention has been attributed to the financial scandals of 2001-2002 that highlighted the harmful effects of short-termism as well as the growing interest in the potentially positive role that environmental, social, and governance (ESG) factors can play in improving long-term performance. ${ }^{42}$

Consternation about short-termism intensified with the collapse of some venerable financial firms in 2008 and the threat it posed to the stock markets, economy and the society at large. ${ }^{43}$ The development raised questions about the role that an obsession with short term results by investors played in the debacle and revived a decades-old debate about how to curb the excesses of short-termism, while encouraging long term investing. ${ }^{44}$ On one side of the debate are those who strongly view shorttermism both as the culprit and as a continuing threat to the economy.

36 Wong, supra note 35 .

37. Id.

$38 \mathrm{Id}$ :

39 Id.

40 See Beale \& Fernando, supra note 17 , at 27.

41 See Tonello, supra note 30 , at i 3.

42 David Hess, Public Pensions and the Promise of Shareholder Activism for the Next Frontier of Corporate Governance: Sustainable Economic Development, 2 VA. L. \& BuS. REv. 221,224 (2007).

43 See, e.g., Lawrence Mitchell, Protect Industry from Predatory Speculators, Fin. Times (London), July 8, 2009, http://www.ft.com/intl/cms/s/o/fac88 I b6-6be5-I I de-9320-00144feabdco.html\#axzz I deHJelKG.

44 See Beale \& Fernando, supra note 17, at 27 (stating that the debate surrounding the existence, cause and possible solutions to the issue of short-termism began in the $1980 \mathrm{~s}$ ). 
Opposing them are those who dismiss the thought that short-termism is indeed a problem that warrants any form of public or private intervention. ${ }^{45}$

\section{Arguments Supporting Existence and Regulation of Short-termism.-Dome} corporate and securities law scholars view investing with a short-term horizon as hazardous. ${ }^{46}$ Their concern stems from reasoning that shortterm-driven corporate policy or practice often translates to the pursuit of investments that are profitable in the short term, but unsustainable in the long run. They see the current activism of hedge funds and other institutional shareholders focused on immediate gains as detrimental both to the well-being of the corporation and the public. ${ }^{47}$ The Conference Board summarizes the problem as follows:

On a macro-economic level, short-term visions are the cause for market volatility and the instability of financial institutions. From the micro-economic standpoint, they undermine management continuity and expose a public company to the risk of losing sight of its strategic business model, compromising its competitiveness. In addition, the pressure to meet short-term numbers may induce senior managers to search for a number of business costs (i.e. the cost of a state-of-the-art pollution control system) to externalize, often to the detriment of the environment and future generations. ${ }^{48}$

The contention is that where management pays undue attention to quarterly earnings per share, it may put on hold or jettison investments

45 For an extensive and excellent discussion of the causes of short-termism, see Lynne Dallas, Short-termism, the Financial Crisis and Corporate Governance, 37 J. CoRp. L. 265 (2012)..

46 See Ed Waitzer, The Case for Realigning Shareholder Incentives, Globe \& Mall (Canada), Jan. 25, 2010, at B8 (viewing short-termism as hazardous); see also Lawrence E. Mitchell, The Sarbanes-Oxley Act and the Reinvention of Corporate Governance?, 48 VILL. L. REv. I 189, I210 (2003) [hereinafter Mitchell, Sarbanes-Oxley] ("Short-term investing breeds excessive volatility and damages investor confidence in the markets. Short-term investing pressures managers to engage in short-term management, damaging the future prospects of the corporation with promiscuous layoffs, inadequate funding for research and development, environmental pollution and substandard production quality. Short-term investing drives managers to manage earnings, not business.").

47 Waitzer, supra note 46 ("Simply put, what you do for the short term is often opposed to what you want (or what is socially desirable) in the long term."); see also Stephen Bainbridge, The Fruits of Shareholder Activism, ProfessorBainbridge.com (June 3, 2010, 1 1:25 AM), http:// www.professorbainbridge.com/professorbainbridgecom/2010/06/the-fruits-of-shareholderactivism.html (responding to a recent shareholder struggle in the biotechnology industry and arguing that proceeding with then contemplated legislative changes on shareholder empowerment would further enable short-term oriented shareholders to "pursue their private gains at the expense of other shareholders and the public good"); (f. Oppold, supra note 29, at 869-70 (indicating that hedge fund investors may not always hurt companies long-term performance).

48 Tonello, supra note 30 , at 42. 
that increase long-term. value but negatively affect near-term earnings. ${ }^{49}$ Empirical basis for this conclusion exists. Some studies have found that Research and Development ("R\&D") cuts are quite likely in companies where the dominant shareholders are "transient" institutions, i.e., those with high portfolio turnover and robust trading strategies. ${ }^{50}$ A survey of over .400 financial executives revealed that more than 80 percent of the respondents would reduce discretionary spending in the areas of $R \& D$, advertising, maintenance, and hiring to meet short-term earnings targets. ${ }^{51}$ Fifty percent responded that they would delay new projects, even when such delay translates to sacrifices in value creation. ${ }^{52}$

According to the Aspen Institute, those asset managers that thrive on "a primary focus on short-term trading gains have little reason to care about long-term corporate performance or externalities, and so are unlikely to exercise a positive role in promoting corporate policies, including appropriate proxy voting and corporate governance policies, that are beneficial and sustainable in the long-term." 53 Thus, some commentators conclude that an emphasis on short-term results "makes it increasingly difficult for the corporation to maintain the long-term focus necessary to its own and society's well-being." 54

Conversely, long-term shareholders have interests that go beyond immediate stock price maximization, and thus are better positioned to advocate corporate policies that are in alignment with general societal expectations of corporations. ${ }^{55}$ Indeed, to the extent that companies get

49 William W. Bratton \& Michael L. Wachter, The Case Against Shareholder Empowerment, I 58 U. PA. L. Rev. 653, 702 (2010).

50 Id. at 702-03 n.I54; see also Brian J. Bushee, The Influence of Institutional Investors on Myopic R\&D Investment Behavior, 73 ACCT. REv. 305, 306 ( 1998) ("Myopic investment behavior is a type of earning management that is most likely to happen when managers face a trade-off between meeting earnings targets and maintaining R\&D investment.").

5I Kurt N. Schacht, Breaking the Short-Term Cycle, in Fourth Annual Director's InStiTUTE on Corporate Governance, at 583, 591 (2006).

52 Id. But see George W. Dent, Jr., The Essential, Unity of Shareholders and the Myth of Investor Short-Termism, 35 DEL. J. CoRP. L. 97, 126-28 (2010).

53 ASPEN INST,, supra note I8, at 2.

54 Martin Lipton \& Steven A. Rosenblum, A New System of Corporate Governance: The Quinquennial Election of Directors, 58 U. CHI. L. Rev. I87, 203 ( I991); see also. Beale \& Fernando, supra note 17, at 26-27 ("[Short-termism is] counterproductive for long run economic growth as well as social cohesion and environmental sustainability. It discourages long-term considerations such as the environment, or social responsibility."); Lawrence E. Mitchell, $A$ Critical Look at Corporate Governance, 45 VAND. L. Rev. 1263, 1292-94 (1992) (arguing that shorttermism impedes management focus on long term goals, including social goals).

55 See, e.g., Hess, supra note 42, at 228-29 (stating that while a short term focus ignores or exacerbates environmental conditions, a long-term focus embraces environmental considerations in the march toward economic growth); Jennifer Hill, Pension Funds Must Heed Climate Change: Gore, Reuters, Mar. 14, 2007, http:/www.reuters.com/article/2007/03/14/us-britainpensions-gore-idUSL 14541139200703 14. 
fixated on the near-term, the failure to give proper attention to social, ethical, or environmental issues may lead to reputational damage, stock price volatility and increase in the cost of capital. ${ }^{56}$ Arguably, long-term investors may be concerned about social and environmental issues, not because of any deep and abiding interest in these issues but because they recognize that ignoring them may ultimately pose a significant danger to their financial bottom line ${ }^{57}$ Considering the problem from that perspective, long term enthusiasts suggest that public policy should identify with the interests of long-term shareholders and either curtail the power of short horizon investors or attach appropriate responsibility to accompany the exercise of that power. ${ }^{58}$

3. Arguments Denying Short-termism and Against Regulation.-Not every corporate scholar accepts the foregoing arguments. Defense of investor short-termism takes a number of forms. One category of defenders doubts its existence or claim it is a managerial, not a shareholder, problem. ${ }^{59}$ Professor George Dent's observation below encapsulates this school of thought:

First, "for all the anecdotal evidence of short-termism and its effects, there is not a lot of empirical data to back it up." "[N] o one has demonstrated that the long/short phenomenon exists . ..." Undoubtedly some investors trade on the basis of shortterm performance, but this is no more important than that some investors trade on the basis of astrology. All that is needed for

56 Cynthia A. Williams \& John M. Conley, An Emerging Third Way? The Erosion of the Anglo-American Shareholder Value Construct, 38 CoRNELL INT'L L.J. 493, 547 (2005).

57 Marleen A. O'Connor, Organized Labor as Shareholder Activist: Building Coalitions to Promote Worker Capitalism, 3 I U. RıCH. L. REv. 1345, I 350 (1997) ("patient investors are beginning to evaluate aspects of labor relations not on social grounds, but as indicators of companies" potential to innovate in an intensely competitive environment."); Jason S. Johnston, Signaling Social Responsibility: On the Law and Economics of Market Incentives for Corporate Environmental Performance I I (U. Pa. L. Sch. Inst. for L. \& Econ., Research Paper No. 05-16, 2005), available at http://ssrn.com/abstract $=725 \mathrm{I} 03$ (stating that a rational investor is concerned about regulatory liability and compliance costs because they affect the firm's financial bottom line even when such investor may not care about third party harms in the form of pollution or unfavorable working conditions).

58 Apart from public policy calls, analysts also sound a note of caution about the implications of obsession with short-term investing, pointing attention to the 1929 stock market crash, which shares a similar characteristic of short holding periods. See Justin Lahart, Wrong Way? Street Signs Point to Speed, Wall St. J., Feb. 26, 2007, at C1.

59 George W. Dent, Jr., Corporate Governance: Still Broke, No Fix in Sight, 31 J. Corp. L. 39, 54 (2006) ("Claims that investors promote detrimental 'short-termism' are also ill-founded."); see also George W. Dent, Jr., For Optional Federal Incorporation, 35 J. CoRP. L., 499, 514 (2010) (stating that credible evidence of significant shareholder short-termism is lacking and that the self-centered incentives of executives, not shareholder pressure, account for whatever short-termism problem that exists). 
markets to be efficient is a critical mass of rational investors. "[C]ompetition among investors who do not suffer from a shortterm bias will drive stock price toward an unbiased level." 60

Some of the defenders of short-termism have relied on the efficient capital markets hypothesis ("E.C.M.H.") which posits that the present value of a company's long-term position is reflected in the short-term price of its stock. ${ }^{61}$ That being the case, investor orientations, whether short or long-term, are immaterial. ${ }^{62}$ In that connection, one scholar notes that "the 'short-termism' argument depends on the belief that the stock market systematically undervalues companies that pursue long-term investment projects ...," adding that the "belief does not seem to be supported by the evidence." 63

The E.C.M.H., however, has "fallen into serious disrepair" in recent years, with contemporary theorists "conced[ing] that stock market prices often depart substantially from reasonable estimates of fundamental economic value." ${ }^{4}$ Some scholars contend that "some of the assumptions underlying the E.C.M.H. may be overly optimistic, particularly those regarding the ability of the market to accurately value long-term risks and investments." ${ }^{65}$ Indeed, the financial crisis of 2008 revealed significantly

60 George W. Dent, Jr., Stakeholder Governance: A Bad Idea Getting Worse, 58 CASE W. REs. L. Rev. I 107, I 1 10 (2008) (alterations in original) (citations omitted); see also George W. Dent, Jr., Academics in Wonderland: The Team Production and Director Primacy Models of Corporate Govemance, 44 Hous. L. REv. 1213, I235-39 (2008) (questioning the assumption that there was a conflict between short- and long-term investors).

6I See Rebecca A. Crawford, Corporate Governance Reform: How to Promote the Long-Term Health and Value of U.S. Corporations, 5 N.Y.U. J. L. \& Bus. 905, 918 (2009). For a critical appraisal of the efficient markets hypothesis, see Jeff Schwartz, Faimess, Utility, and Market Risk, 89 OR. L. Rev I 75, $201-08$ (2010).

62 Crawford, supra note 61, at 918; see also Mark. G. Robilotti, Codetermination, Stakeholder Rights, and Hostile Takeovers: A Reevaluation of the Evidence from Abroad, 38 HARv. INT'L L.J. 536, 565 (1997) ("In the 1990s] several scholars argued that even if managers are focused on the short-term, the stock market operates efficiently over the long term.").

63 Donald W. Kiefer, The Security Transactions Tax: An Overviexw of the Issues, 48 Tax Notes 885, 895 ( I990); see also G. William Schwert \& Paul J. Seguin, Securities Transaction Taxes: An Overview of Costs, Benefits and Unresolved Questions, Fin. AnALYST J., Sept.-Oct. 1993, at 27, 29.

64 Iman Anabtawi \& Lynn Stout, Fiduciary Duties for Activist Shareholders, 60 STAN. L. REv. 1255, 1291 (2008); A Different Class: Would Giving Long-Term Shareholders More Clout Improve Corporate Governance?, Economist, Feb. 20, 2010, at 66 [hereinafter $A$ Different Class] ("Shareholders can no longer with a straight face cite the efficient-market hypothesis as evidence that rising share prices are always evidence of better prospects, rather than of an unsustainable bubble.").

65 Williams \& Conley, supra note 56, at 502 n..38; see also Lynn A. Stout, The Mechanics of Market Inefficiency: An Introduction to the Nero Finance, $28 \mathrm{~J}$. CoRP. L. 635, 637 (2003) ("[I]t is difficult for a disinterested observer not to suspect that efficient market theory fails, in some fundamental respect, to capture the reality of securities markets."); $c f$. GeORGE A. AkERLOF \& Robert J. Shiller, Animal Spirits: How Human Psychology Drives the Economy, and Why It MATTERS fOR Global CAPITALISM I 32 (2009) ("To pretend that stock prices reflect people's 
different outcomes for short and long run investors and questioned the notion that markets always reflect fundamental value or that investors are always purely rational in their approach to trading. ${ }^{66}$

Another category of defenders is willing to acknowledge concerns with short-termism but reluctant to figuratively throw out the baby with the bathwater. ${ }^{67}$ They note that corporate managers have long relied upon the long horizon argument as a smokescreen to hide their lackluster performance and ward off activist investors intent on energizing underperforming corporations. ${ }^{68}$ Along similar lines, support for shortterm shareholding has also stemmed from the angle that some evidence, although inconclusive, indicate that the efforts of short-term shareholders, especially activist hedge funds, can positively affect the fortunes of poorly run target companies. ${ }^{69}$

Indeed, a short-term outlook is not intrinsically wrong. ${ }^{70}$ That investment decisions are made from a short term perspective does not automatically imply that they are inferior. ${ }^{71}$ Similarly, bad decisions may

use of information about those future payoffs is like hiring a weather forecaster who has gone berserk.").

66 Akerlof \& SHILler, supra note 65, at 36-37; Nina Walton, On the Optimal Allocation of Power Between Shareholders and Managers i i n.5 (Univ. of S. Cal. Ctr. in Law, Econ., \& Org., Research Paper No. Cio-12, 2010) available at http://papers.ssrn.com/sol3/papers.cfm?abstract_ id= 1654165 ("[S]hort-run investors in investment banks benefited greatly from these banks investing in sub prime mortgage securities, while long-run investors experienced either a significant drop in the value of their equity or a complete wipe-out.").

67 See Marcel Kahan \& Edward Rock, Hedge Fund Activism: The Case for Non-Intervention, Admin. \& Reg. L. News, Winter 2008, AT 6, 7; Kahan \& Rock, Hedge Funds, supra note 2 I, at I $083-91$.

68 Joe Nocera, A Defense of Short-Termism, N.Y. Times, July 29, 2006, at CI; see also Mark J. Roe, Strong Managers, Weak Owners: The Political, Roots of American Corporate FiNANCE 242-43 ( 1994) (criticizing managers fear of takeovers by short-term investors); Joseph A. Grundfest, Just Vote No: A Minimalist Strategy for Dealing with Barbarians Inside the Gates, 45 StAN. L. REv. 857, 870-73 (1993) (discussing the state of many companies that were takeover targets and their post-takeover status); Michael C. Jensen, The Takeover Controversy: Analysis and Evidence, 4 Midland Corp. Fin. J. 6, I I (1986) (discussing the argument that the fear of takeover induces myopic behavior in corporate managers, leading to jettisoning by the managers of long-term benefits for the purpose of increasing short-term profits, but arguing that such managers may be mistaken, in which case it is more beneficial to the corporation and the economy to remove them and create room for a change in strategy and more efficient deployment of resources).

69 A Different Class, supra note 64; Oppold, supra note 29, at 870.

70 Kuang-Wei Chueh, Is Hedge Fund Activism New Hope for the Market?, 2008 Couum. Bus. L. REv. 724, 743 (noting that long-term wealth creation may be consistent with the pursuit of short-term interest but that "concern arises only when short-term interest conflicts with the company's long term interest and the latter outweighs the former.").

7I See Alison Atherton et al., Inst. for Sustainable Futures, Paradigm Shift to Long-Termism: Action Plan for the Australian Finance Sector 2 (2007) [hereinafter Atherton, Paradigm ShIFT], http://www.isf.uts.edu.au/publications/athertonetal2007paradigmshift.pdf. 
also be grounded on a long term perspective..$^{12}$ One scholar persuasively reasons that "it is not clear that a long-term investment horizon is always better than a short-term one. Investing for the long term entails greater risks and opportunity costs than investing for the short term. One cannot always sacrifice the present for the future." ${ }^{3}$ Investors make the balancing decision considering a variety of variables, including their level of tolerance for risk. Accordingly, the argument goes, the law ought to tread softly and preferably should not take sides on the issue. ${ }^{74}$ In addition, the interests of long-term and short-term investors can coalesce to impel managers to act in the best interests of the corporation, for instance, by pushing managers to drop capital investments and acquisitions that add little value or to distribute excess cash to investors. ${ }^{75}$ Moreover, and perhaps more significantly, investors who trade on the short-term provide needed liquidity and stability in the stock markets. ${ }^{76}$

In summary, it is proper to "recognize that there is a valid role and function for all types of horizons and approaches to investment." 77 The problem with short-termism is when it detrimentally conflicts with the company's long-term interest. ${ }^{78}$ The following three parts evaluate proposals that are currently at the top of the short-termism discourse. These proposals fall into two categories, namely public and private. ${ }^{79}$ Two prominent public

72 Id.

73 Julian Velasco, Taking Shareholder Rights Seriously, 41 U.C. Davis. L. Rev. 605, 637 (2007) [hereinafter Velasco, Shareholder Rights].

74 Id.

75 Kahan \& Rock, Hedge Funds, supra note 21 , at 1088-89.

76 Atherton, Paradigm Shift, supra note 7I, at 2 ("[A] degree of short-termism is needed for market liquidity."); Damon Silvers, Commentary on "Toward Common Sense and Common Ground? Reflections on the Shared Interests of Managers and Labor in a More Rational System of Corporate Governance" by Leo E. Strine, Jr., 33 J. CoRp. L. 85, 92 (2007) (arguing that short-term investing is not an unmitigated bad because " $[\mathrm{m}]$ arginal traders contribute information to the market place through continual evaluations of company prospects, and their activities provide liquidity to all investors when they need it"); Mitchell, Sarbanes-Oxley, supra note 46, at 1209 ("[S]pecialists and market makers at least stabilize the market by matching supply and demand."); see also Lynn A. Stout, Are Stock Markets Costly Casinos? Disagreement, Market Failure, and Securities Regulation, 8I VA. L. Rev. 61 I, 683 (1995) [hereinafter Stout, Casinos] (“'Liquidity' refers to an investor's ability to sell an asset quickly without having to offer a discount from the prevailing market price."); Tarun Chordia et al., Fed. Reserve Bank of N.Y., Common Determinants of Bond and Stock Market Liquidity: The Impact of Financial Crises, Monetary Policy, and Mutual Fund Flows I (200I), available at htcp://www.newyorkfed. org/research/staff_reports/sr 141.heml ("Liquidity ... can be defined as the ability to buy or sell large quantities of an asset quickly and at low cost.").

77 Mercer \& IRRC Inst., Investment Horizons: Do Managers Do What They Say? 2 (2010).

78 See Kuang-Wei Chueh, supra note 70, at 743.

79 See Kelly \& White, supra note I 2, at 774-75 (stating that a number of institutions have proposed solutions to the short-termism problem including the Aspen Institute, the Conference Board, the UK's Marathon Club and Australia's Institute for Sustainable Futures). 
policy proposals are an excise tax on securities transactions and capital gains tax reform. On the private front, the idea of a loyalty dividend is one that is gaining increasing attention in the corporate governance discourse. ${ }^{80}$ The common feature of these proposals is that their proponents' primary objective appears to be a strong interest in ensuring that people own shares for a considerable period of time and thus take an "ownership approach" to their interest in the corporation, instead of seeing themselves as tourists, guests, or renters trying to make the best of their temporary stay, without adequate regard to what happens when they leave. ${ }^{81}$

Additionally, the proposals proceed on the understanding that at the end of the day, one is unlikely to count on the active involvement of longterm shareholders in the absence of clear incentives. On the same note, short-term investors are not likely to change their investment patterns unless the incentive to continue disappears. In essence, it is unlikely that investor behavior will change without the appropriate incentives. ${ }^{82}$

\section{Securities Transaction Tax}

\section{A. Preliminary Points}

The idea of deploying a securities transaction tax to address perceived problems in the financial world is not exactly of recent vintage. John Maynard Keynes proposed a stock transfer tax many decades ago to "mitigat[e] the predominance of speculation over enterprise in the United States." ${ }^{83}$ In the 1970s, Nobel Economics Laureate James Tobin proposed a financial transactions tax for the foreign currency markets to curb speculation in cross country trades by taxing away quick gains on such speculation. ${ }^{84}$ This

80 See Waitzer, supra note 46 (stating that the idea of loyalty dividends have been proposed in the Netherlands for shareholders who hold bank shares for at least four years); ATHERTON, PARADIGM ShIFT, supra note 7I, at I6 (recommending investigation into "the feasibility and effectiveness of a scheme to incentivize long-term investment by rewarding longer-term shareholding through additional dividends").

8I This issue has become persistently problematic. See Robert KuTTNER, The Squandering of America: How the Failure of Our Politics Undermines Our Prosperity 144 (2007); see also Jennifer G. Hill, Then and Now: Professor Berle and the Unpredictable Shareholder, 33 Seattle U. L. Rev. I005, 101 I (20 I o) [hereinafter Hill, Unpredictable Shareholder] (restating an observation that some institutional investors' practices portray them more as financial traders than owners or joint managers of the corporation).

82 Atherton, Paradigm Shift, supra note $7 \mathrm{I}$, at 3 ("[W]ithout specifically constructed long-termism incentives, investor behavior will not change.")

83 John Maynard Keynes, The General Theory of Employment, Interest, and Money 160 (Harcourt, Brace \& World I964) (1936).

84 James Tobin, A Proposal for International Monetary Reform, 4 E. EcoN. J. 153, I 55 (1978) [hereinafter Tobin, Monetary Reform]; see Amy Youngblood Avitable, Saving the World One Currency at a Time: Implementing the Tobin Tax, 80 WASH. U. L.Q. 39I, 392 (2002) (stating that the tax was originally valued at one percent but was subsequently reduced); Rolf $\mathrm{H}$. Weber, Challenges 
disincentive tax is specifically designed to place an extra weight on fastmoving capital in order to reduce short-term speculation without damaging the long-term benefits of exchange. ${ }^{85}$ Thus, it deviates from the central purpose of taxation, which is to raise revenue. ${ }^{86}$ Instead, the transaction tax has a closer affinity to the "sin taxes" imposed on alcohol and tobacco consumption in the belief that resulting higher prices of these products will make consumers disinclined to use them. ${ }^{87}$ According to Professor Tobin,

for the New Financial Architecture, 31 HoNG KoNG L.J. 241, 252 (2001) (describing the Tobin tax as a disincentive tax); see also Enrique R. Carrasco \& Kristen J. Berg, Praxis-Oriented Pedagogy: The E-Book on International Finance and Development, 32 Loy. L.A. L. REv. 733, 744 (I999) (examining Tobin's financial transaction tax); Tobin Tax Initiative, CTR. For ENVTL. ECON. DEv., http://www.ceedweb.org/iirp/ (last visited Dec. 30, 2011) (providing informational links on Tobin Taxes); Fact Sheet on Tobin Taxes, CTr. For ENVTL. Econ. Dev., htcp://www.ceedweb. org/iirp/factsheet.htm (last visited Oct. 16, 2009) (outlining how Tobin Taxes function); $c f$. Thomas I. Palley, Speculation and Tobin Taxes: Why Sand in the Wheels Can Increase Economic Efficiency, 69 J. EcON. I 13, 122-24 (1999) (highlighting the policy arguments for a Tobin Tax).

85 Robin Paul Malloy, Mortgage Market Reform and the Fallacy of Self-Correcting Markets, 30 PACE L. Rev. 79, I 10 (2009); Timothy A. Canova, Banking and Financial Reform at the Crossroads of the Neoliberal Contagion, 7 U.S.-Mex. L.J. 85, 113 (1999); Michael J. Graetz \& Itai Grinberg, Taxing International Portfolio Income, 56 TAx L. Rev. 537, 554 (2003); James Tobin, International Currency Regimes, Capital Mobility and Macroeconomic Policy, I5 GReEK Econ. Rev. I, I I (I993) ("These markets are engines that work all too well technically but do not work all that well economically, especially macro-economically. The sand in the wheels would take the form of transactions taxes, which direct trader's attention to long-run fundamentals and away from transient contagious market sentiment."); see also James Tobin, The New Economics ONe Decade Older 89 (1974) (expounding the financial transactions tax).

86 Geoffrey G.B. Brow, The Tobin Tax: Tuming Soros into Plozoshares?, 9 Transnat'L L. \& Contemp. Probs. 345, 376 (I999). The ability of the tax to raise significant sums of money that can be put into diverse uses cannot easily be discounted, but the primary purpose, as Professor Tobin argued, is to discourage persons interested in reaping a quick gain from a round-trip trade to another currency, thereby limiting volatility and promoting stability. Tobin, Monetary Reform, supra note 84, at 153-59; see also Amy McFarlane, In the Business of Development: Development Policy in the First Two Years of the Bush Administration, 2 I BerkelEY J. INT'L L. 521,538 (2003) (discussing a German feasibility study suggesting that a Tobin tax "could provide stability for exchange markets and discourage speculation while providing an intergovernmental organization, such as the U.N., with increased funds for development aid"). For a discussion of the revenue-raising potential of the Tobin tax and a sampling of the various uses to which the proceeds may be put, see Kok-CHOR TAN, Justice Without Borders: Cosmopolitan, Nationalism, and Patriotism 80-81, 94-95 (2004). See also David E. Pozen, Tax Expenditures as Foreign Aid, I 16 YALE L.J. 869, 879 (2007) (suggesting that there are numerous uses for the tax revenue); Paulette L. Stenzel, Why and How the World Trade Organization Must Promote Environmental Protection, I 3 Duke EnvTl. L. \& PoL'y F. I, 40 (2002) ("Funds raised from this tax would be used to provide funds for sustainable development projects in poor countries."); William R. White, Note, The Tobin Tax: A Solution to Today's International Monetary Instability?, 1999 Colum. Bus. L. Rev. 365, 389 (1999) ("[T]he revenue raised by the ['Tobin] Tax would be substantial, and could be used either by individual nations or international organizations to fund their activities."). See generally Myron Frankman, Beyond the Tobin Tax: Global Democracy and a Global Currency, 581 Annals Am. Acad. Pol. \& Soc. Sci. 62 (2002) (discussing the Tobin Tax and alternative solutions to the challenges of the global economy).

87 Brow, supra note 86, at 376; see William N. Thompson, Gambling Taxes: The Philosophy, 
the transaction tax "would automatically penalize short-horizon round trips, while negligibly affecting the incentives for commodity trade and long-term capital investments."

\section{B. Arguments in Favor of a Securities Transaction Tax}

It is with regard to the stock market that this excise tax proposal has been resurrected and gaining increasing fervor ${ }^{89}$ The extension of the tax to stocks is not expected to diminish the value of the shares but may be beneficial in addressing problems associated with buying stocks and selling them too rapidly. ${ }^{90}$ The essence of this tax is to reduce the incentive for short-term trades by taking away the profit motivation for such transactions and thus induce the traders to change their behavior in the direction of long term shareholding.9" "So, a built-in effect of this idea is to encourage the 'rational person' to invest for the long-term by minimizing the impact

the Constitution and Horizontal Equity, I 7 VILL. SPORTs \& ENT. L.J'· 389,406 (2010) ("High taxes on liquor, for instance, have been justified on the basis that the tax will add to the cost of liquor and thereby discourage consumption of a 'bad' thing."); see also Theresa A. Gabaldon, John Law, with a Tulip, in the South Seas: Gambling and the Regulation of Euphoric Market Transactions, 26 J. CoRp. L. 225, 24I-46 (200I) [hereinafter Gabaldon, Euphoric Market] (analogizing stock market speculation to gambling and calling for a transactions tax, among other proposals, to remedy the problem).

88 James Tobin, Prologue to The Tobin Tax: Coping with Financial. Volatility, at xi (Mahbub ul Haq et al. eds., 1996).

89 See, e.g., AsPEN INST., supra note I 8, at 3 (recommending an excise tax on stock market transactions to curb short-term investing); CTR. For Econ. \& Policy Research, Sup port for a Financial Transactions Tax (FTT) (20I I), http://www.cepr.net/documents/ftt-support.pdf (last visited Dec. 3I, $201 \mathrm{I}$ ) (providing a long list of supporters for a tax on the financial services industry).

90 See, e.g., LowENSTEIN, supra note 26 , at $86-87$ (referencing proposed taxation of gains from sale of stocks or derivatives held for less than a year at Ioo percent); Caroline Bradley, Disorderly Conduct: Day Traders and the Ideology of "Fair and Orderly Markets", 26 J. CoRP. L. 63, 94 (2000) (referencing a proposal by the Center for Economic and Policy Research to tax securities transactions as a way of discouraging speculation); Robert Hockett, What Kinds of Stock Ownership Plans Should There Be? Of ESOPs, Other SOPs, and "Ownership Societies", 92 ConNELL L. REv. 865, 939 (2007) (arguing that such a tax could be used to address speculative tendencies by those who receive public assistance to invest in the stock market).

9I The same rationale applies in the currency context. See Joseph M. Schwartz, Democracy Against the Free Market: The Enron Crisis and the Politics of Global Deregulation, 35 ConN. L. REv. 1097, $1120-2$ I (2003). ("Imposing a global 'Tobin tax' on all transfers of liquid capital (stock and bond market investments and short-term bank deposits) would decrease the incentive for short-term capital flight aimed at disrupting sovereign nation-state policy."); Roman Terrill, Coping With Private Capital Markets, 9 Transnat'L L. \& Contemp. Probs. 304, 3 I I ( 1999 ) ("A tax on spot-currency transactions may prompt investors to reduce their short-term holdings of a currency and increase their longer-term holdings. If an investor has a long-term interest in the sustained value of the currency, he is less likely to benefit from its near-term depreciation."). 
of the tax in that case. The primary impact would be on the short-term speculator who uses hedge funds in hopes of turning a quick profic." 92

Some economists have argued that strong efficiency arguments can be made in favor of a modest transactions tax to slow down the financial markets, adding that these "efficiency benefits from curbing speculation are likely to exceed any costs of reduced liquidity or increased costs of capital that come from taxing transactions more heavily." ${ }^{33}$ Expressing serious reservations that "investments made with a horizon of hours reveal much socially beneficial information to the market place," in contradistinction to information supplied by investors with long-term investment strategies that helps in determining the fundamental values of assets, they view a transaction tax as "a natural policy for alleviating this market failure." 94 The anticipated effect is a restoration of needed balance in the market by drowning or driving out "noise traders" (who do not trade on the basis of sound information or reasonable prediction) ${ }^{95}$ because the tax "would have a significant impact in making it less attractive to invest resources in various short-term prediction activities, since the tax cost would increase with the frequency of trading." 96

In addition, a transaction tax may also increase economic efficiency if it succeeds in discouraging purely rent-seeking speculative behavior, which diverts resources to "treasure hunting" instead of devotion to genuinely productive activities that benefit society. ${ }^{97}$ Noting that excessive expenditures are deployed toward information gathering and financial innovation, Nobel Economics Laureate Joseph Stiglitz argues that, inasmuch as the tax will discourage the disproportionate expenditures devoted to this form of "rent-seeking," it serves to promote economic efficiency. ${ }^{98}$ "It can thus be viewed as a special and potentially important case of a Pigovian corrective tax, a tax that improves economic efficiency at the same time that it raises revenues." 99

A transaction tax is also expected to address the twin manifestations of investor short-termism. First, it could lengthen the investment horizons

92 Carrasco \& Berg, supra note 84 , at 744.

93 Lawrence H. Summers \& Victoria P. Summers, When Financial Markets Work Too Well: A

Cautious Case for a Securities Transactions Tax, 3 J. Fin. Services Res. 261, 263 (1989).

94 Id. at 272.

95 See Paul G. Mahoney, Is There a Cure for "Excessive" Trading?, 8I VA. L. Rev. 713, 718-19 (1995) (describing noise trading, its participants and effects); Steven L. Schwarcz, Temporal Perspectives: Resolving the Conflict Between Current and Future Investors, 89 MinN. L. Rev. 1044, $108 \mathrm{I}$ (2005) (stating that noise trading leads to market inefficiency).

96 Summers \& Summers, supra note 93, at 272.

97 See John Karl Scholz, Comments on "Adverse Implications of a Securities Transactions Excise Tax" by Joseph A. Grundfest and John B. Shoven, 6. J. AccT., Audiring \& Fin. 443, 444 (I991).

98 Joseph E. Stiglitz, Using Tax Policy to Curb Speculative Short-Term Trading, 3 J. Fin. Services Res. IOI, 103 (1989).

99 Id. 
of corporate managers. ${ }^{100}$ By driving out those investors whose irrationality poses a stumbling block to looking beyond the immediate situation, companies would be more tolerant of investments with long-term payoffs but which lead to reductions in quarterly earnings. ${ }^{101}$ Also, when investors pursue an investment strategy that consistently consists of holding stock for a longer period of time, it sends a signal to management that it is free to pursue more long-term strategies. ${ }^{102}$ Secondly, "transaction taxes that tie shareholders to firms may induce shareholders to take a more active role in monitoring management and insuring that proper planning and investment activities take place." 103 Thus, transaction taxes aim to replace shareholder exit with shareholder voice on the assumption that since the cost of exit is significantly raised by the tax, dissatisfied shareholders, instead of leaving for other companies, would be impelled to stay and seek avenues to influence or displace the management of their companies. ${ }^{104}$

Some scholars have found evidence that a transaction tax would drive down speculation. ${ }^{105}$ Supporters of a transactions tax also suggest that it will reduce volatility by decreasing trading. ${ }^{106}$ This will be beneficial to investors and firms. According to Stiglitz, "to the extent that volatility would be reduced, the buyer of the security bears less risk concerning the price he or she will receive when he or she sells it. Thus, reducing the volatility will make it easier for firms to raise equity capital." ${ }^{107}$ A secondary

I00 Id. at 109 (stating that unlike the case of short-term speculators, the effect of the tax on an investor who plans to hold stock for 20 years is negligible; and if the tax thereby leads to an increase in the number of long-term investors, corporate managers, freed from pressure from short-term oriented investors, would direct their attention toward the long term).

Iol Summers \& Summers, supra note 93 , at 273.

102 Id.

$103 I d$

104 Id. at 273-74; see also René M. Stulz, Comment, in The Internationalization of EQUITY MARKETS 303, 304 (Jeffrey Frankel ed. 1994) (stating that when trading is cheap, investors may sell their stock if dissatisfied with management, but if the cost of trading increases, "investors become locked into their holdings and can increase the performance of their portfolios through actions designed to improve the performance of management. ... [and that because transactions taxes] increase the cost of trading, this reasoning implies that they increase the monitoring of management and hence improve corporate performance")

I05 John Y. Campbell \& Kenneth A. Froot, Intermational Experiences with Securities Transaction Taxes, in The INTERnationalization of EOUITY MARKETs, supra note 104, at 277, 296 ( showing from case studies that investor response to transactions taxes could take the form of a reduction in the volume of taxable transactions, adding that "some econometric evidence for this behavior" also exists).

106 See Stulz, supra note 104, at 305.

107 Stiglitz, supra note 98 , at 108. 
benefit of a transaction tax is the substantial amount of tax revenue that it would generate. ${ }^{108}$

\section{Arguments Against a Securities Transaction Tax}

Notwithstanding the foregoing arguments in support of a securities transaction tax, pertinent questions pertaining to the viability, efficacy and acceptability of this type of tax in the context of short term stock trading still persist. The tax proposal confronts the natural hostility of corporate finance to regulation of financial capital, as exemplified by the strong opposition to the imposition of a Tobin tax on the withdrawal by foreign investors of investments in national stock or money markets. ${ }^{109}$ Opposition from the securities industry also marked and marred a planned introduction of a Securities Transaction Excise Tax as part of the 1990 budget negotiations. ${ }^{110}$

More substantively, some of the assumptions behind the tax may be overly optimistic. One example is investor monitoring of managerial behavior. Even supporters of the tax doubt its efficacy in pushing shareholders along those lines, in view of the free rider problem. ${ }^{11}$ Shareholders evince a legendary reluctance to engage alone in causes that would redound to the benefit of all. ${ }^{112}$ Similarly, a shareholder would prefer to wait for other shareholders to take charge of the battle, while she lurks in the sidelines, convinced that she cannot be excluded from its benefits that accrue to all. ${ }^{113}$ In addition "for investors who can find ways to alter the

108 See Scholz, supra note 97, at 443.

109 Schwartz, supra note 91, at 1108.

1 Io See Joseph A. Grundfest \& John B. Shoven, Adverse Implications of a Securities Transactions Excise Tax, 6 J. AccT., Auditing. \& Fin. 409, 410 (1991) (discussing the opposition from various quarters, including the securities and commodities industries, pension fund managers and investors, that trailed a planned adoption of a Securities Transactions Excise Tax (STET) as part of the 1990 budget, and which scuttled the plan); Stout, Casinos, supra note 76 , at 699-700; see also Sanford M. Jacoby, Employee Representation and Corporate Governance: $A$ Missing Link, 3 U. PA. J. LAB. \& EMP. L. 449, 484 (2001); Philip Arestis \& Malcolm Sawyer, How Many Cheers for the Tobin Transactions Tax?, 2 I Cambridge J. Econ. 753, 765-66 (1997) (outlining the obstacles to a transactions tax); $f$. Robert J. Shiller, IrRational Exuberance 226-28 (2d ed. 2005) ("In the interest of longer-run economic stability, it may be that the best stabilizing influence on markets is to broaden them to allow as many people as possible to trade as often as possible.").

I I Summers \& Summers, supra note 93, at 273-74; Stout, Casinos, supra note 76, at 687.

I 2 See Mark J. Roe, A Political Theory of American Corporate Finance, 91 Colum. L. Rev. 10, 12 (1991).

113 Frank H. Easterbrook \& Daniel R. Fischel, Limited Liability and the Corporation, 52 U. CH1. L. Rev. 89, 95 ( 1985). See generally Sanford J. Grossman \& Oliver D. Hart, Takeover Bids, the Free-Rider Problem, and the Theory of the Corporation, I I BELL J. ECON. 42 (I980) (arguing that the free-rider problem makes it unprofitable for small shareholders to undertake the task of monitoring management). 
return distribution of their portfolios without paying the tax, the tax affects how these investors trade but not how they monitor management." 114

Besides, while the tax has the potential to be a force for good, it also carries with it enormous potential to inflict harm. A valid concern is that a transaction tax may "reduce market liquidity, which may discourage investment and increase the risks borne by the owners of capital." 115 Assume that for some reason, a large block of shares of a particular company became available for sale on the exchange. Some investors want to purchase the block, but want a slight price drop as concession. Investors that play this role, enabling such trades to take place, provide liquidity to the markets. As such, the service they provide is an important one. Yet, their intention may not to be to hold on to these shares for a long time. ${ }^{116} \mathrm{~A}$ transaction tax makes such market moves more difficult as the investors providing the liquidity would factor the tax amount into the acceptable price they are willing to pay for the stock to account for the decrease in their profit occasioned by the tax. ${ }^{17}$

Some commentators also vehemently oppose the tax on the basis that it "would represent.a return to the 'bad old days' when politicians and bureaucrats attempted to use taxation to achieve a myriad of worthwhile and not-so-worthwhile non-revenue objectives" adding that the proper role of tax law is to raise revenue, and not a vehicle for accomplishing non-revenue policy goals. ${ }^{118}$ It is logical to assume that because the Rich

114 Stulz, supra note 104, at 304.

115 Summers \& Summers, supra note 93 , at 274 . The scholars respond by arguing that "beyond a certain point, increased liquidity may have costs that exceed its benefits" and that "transactions taxes are in place with respect to most of the world stock markets, and have apparently not reduced liquidity sufficiently to create severe problems." Id.

I I6 Stulz, supra note I04, at 306; Mitchell, Sarbanes-Oxley, supra note 46, at I 209 ("[S] pecialists, market makers and day traders make significant profits by short-term trading, and in so doing they may help to move market prices in the 'right' direction.")

117 Stulz, supra note 104, at 306 . For additional discussion of the importance of liquidity, see Stout, Casinos, supra note 76, at 683-84. According to Stout,

\footnotetext{
Speculative trading can contribute to market liquidity by increasing both the number of traders and the frequency of trading in the market. Liquid secondary markets, in turn, are thought to provide a social benefic by encouraging capital investment. Because investors desire liquidity, they value assets that can be quickly resold more highly than assets that are difficult to convert into cash. The promise of a liquid secondary market is thought to encourage investors to purchase newly issued stocks, lowering firms' cost of capital.
}

Id. For a discussion of the effect on liquidity in the currency context, see Terrill, supra note 91 , at 31 I ("Transaction taxes like these often result in reduced liquidity in the domestic currency market and unwanted decreases in overall capital inflows."); see also Barry Eichengreen, Conclusion: The Tobin Tax: What Have We Learned, in The Tobin Tax: Coping With Financial Volatility 273, 274 (Mahbub ul Haq et al. eds., 1996) (discussing the importance of speculation in providing currency market stability).

I 8 Douglas M. Branson, Book Review, Lawrence E. Mitchell, Corporate Irresponsibility America's Newest Export (Yale University Press, New Haven, Connecticut, 200I), 65 U. PITT. L. Rev. 91 I, 928 (2004); see also Thompson, supra note 87, at 402 ("Revenue production must be the 
constitute a sizeable portion of the investor group, the transaction tax will be a progressive tax, with favorable distributive consequences for the Poor. But the tax may actually be regressive in that the burden would substantially fall on the largely middle class beneficiaries of private pension funds and state and local taxpayers who would be asked to make up any shortfall in the assets of public pension plans resulting from the higher transaction costs. ${ }^{119}$

Another source of objection is that the transactions tax is not limited to trades that take place when stock prices change rapidly. Instead, it would tax every trade, including trades that occur when there is minimal or zero volatility, and thus is likely to inflict enormous costs on society. ${ }^{120}$ Generally, it ensnares and imposes hardship on investors that have virtually no contribution to the speculation problem that it is designed to curb. ${ }^{121}$ These include innocent shareholders who want to sell their stock to meet other financial needs and who have no interest in speculation of any kind. ${ }^{122}$ Thus, the question arises: why not explore alternative policy proposals to target undesirable practices without inflicting harm on those who are not the source of the problem? ${ }^{123}$

Another weakness of the proposed tax is that it will present substantial difficulties of administration, implementation, and compliance. ${ }^{124}$ Close substitutes of covered instruments and traditional trading patterns will emerge to avoid the tax. ${ }^{125}$ If the proposal is implemented only in the United States, there is a legitimate concern that the tax will drive investors

quintessential purpose of taxation."). But see Reuven S. Avi-Yonah, The Three Goals of Taxation, 60 TAX L. Rev. 1, 3-4 (2006) (stating that taxation serves three functions, namely to raise revenue, to redistribute wealth in order to reduce inequality in the society, and to regulate private economic activity, steering it in the direction that the government desires); Reuven $\mathrm{S}$. Avi-Yonah, Taxation as Regulation: Carbon Tax, Health Care Tax, Bank Tax and Other Regulatory Taxes I-2 (Univ. of Mich., Empirical Legal Studies Ctr., Working Paper Series 21, 2010), avai/able at http://law.bepress.com/cgi/viewcontent.cgi? article=1 13 I \& context=umichlwps (outlining the three goals of taxation).

119 Grundfest \& Shoven, supra note I IO, at 411 .

120 Id.

12 I See Stiglitz, supra note 98, at 102 (conceding that "[c]hanges in economic circumstances may lead individuals to wish to change their portfolios, entailing selling some securities and buying others," but noting that such transactions do not constitute the bulk of short-term trading).

122 See Carrasco \& Berg, supra note 84, at 745 (noting that one of the criticisms of the Tobin tax is that "introduces inefficiencies and does not distinguish between 'good' speculation and "bad' speculation").

123 See Mahoney, supra note 95, at 726 ("Even if we assume the existence of noise traders, we should still prefer policy approaches that will minimize unnecessary harm to those market participants who are not noise traders.")

124 See Grundfest \& Shoven, supra note I Io, at 423-26.

125 See id. at 423; see also Carrasco \& Berg, supra note 84, at 745. 
bent on avoiding the tax to other financial centers. ${ }^{126}$ The fact that a number of industrialized countries already have some form of a financial transactions tax, however, weakens the force of this charge. ${ }^{127}$ The tax may also be harmonized with other financial center countries to avoid an exodus of trading activities to those countries. ${ }^{128}$

Despite the issues raised above, the objection retains considerable force. Even if major financial centers agree to coordinate efforts in this regard, some tax-haven countries will seize the opportunity to divert a good volume of business to themselves. ${ }^{129}$ Some of the problems may be cushioned by exempting transactions by foreign participants in the United States from the tax. ${ }^{130}$ However, that would only lead to the devising of various innovative vehicles to circumvent the levy; for instance, by United States citizens trading with shell entities incorporated in other countries. ${ }^{131}$ Similarly, if the tax is structured to tax Americans regardless of where the trading takes place as a way to counter the offshore havens problem, ${ }^{132}$ Americans can avoid the problem by trading through foreign vehicles. ${ }^{133}$ In light of the foregoing, the revenue-raising potential may be overestimated, especially as investors devise means of avoiding it or modify their trading behavior. ${ }^{134}$

Because it would be more cost-effective for large investors to pay for avoidance strategies than it is for small investors, it follows that relative to

126 Carrasco \& Berg, supra note 84, at 745; see also Summers \& Summers, supra note 93, at 280 (discussing opposition to a transactions tax based on the reasoning that "such a tax would cripple the United States securities industry by driving much of the activity of the U.S. financial markets offshore"); Campbell \& Froot, supra note 105, at 278, 292.

127 See Chaka Fattah, De ja` Vu All Over Again: Reexamining Fundamental Tax Reform and Evaluating the Feasibility of a Transaction Tax in the IIrth Congress, 47 HARv. J. ON LEGIS. 327, 353, 355 (2010) (stating that some or other form of transaction tax exists in a number of countries); Jeffrey Frankel, Why Not a Transaction Tax?, Seexing Alpha (Sept. 30, 2008), http://seekingalpha.com/article/97964-why-not-a-transaction-tax (stating that a "lot of countries already have such transactions taxes."); see also Summers \& Summers, supra note 93, at 280 ("[F]ears regarding a drastic reduction in the size of the U.S. securities industry are unwarranted.")

128 Summers \& Summers, supra note 93, at 280; see also Frankel, supra note 127 (stating that a lot of countries "would love to cooperate with the United States in an international program to harmonize such taxes internationally," adding that it "is precisely the sort of thing that many abroad have always asked Americans to participate in, but that we have not hitherto wanted to do")

129 See Summers \& Summers, supra note 93, at 280.

130 Id.

I31 See Grundfest \& Shoven, supra note 1 10, at 432 (noting that exempting foreigners from the tax would "create an incentive for U.S. investors to acquire interests in foreign capital pools able to trade free of the [transactions tax's] burdens").

132 See Summers \& Summers, supra note 93, at 280.

133 Cf. Joseph A. Grundfest, The Limited Future of Unlimited Liability: A Capital Markets Perspective, 102 YALE L.J. 387, 409-10 (1992) (discussing devices to avoid regulatory requirements).

I34 See Campbell \& Froot, supra note 105, at 280. 
large investors, the tax may penalize small investors who either pay the tax or are locked into their holdings. If large investors are able to sell their holdings almost as easily as they would before the tax, thereby availing themselves of the Wall Street Rule, the objective of keeping management from paying attention to short-run performance at the expense of longrun performance is largely defeated; the tax only succeeds in reducing the use of the rule by small investors. The implications are significant: " $[\mathrm{t}]$ ypically, those who are concerned about short-termism tend to blame fund managers rather than small shareholders, so it is difficult to believe that [transaction taxes] do much about short-termism." ${ }^{135}$

While one of the primary objectives of a transaction tax is the reduction of volatility, proponents and antagonists alike acknowledge that it may not be an effective tool in accomplishing that task. ${ }^{136} \mathrm{~A}$ recent empirical study of eight historical events where regulators increased transaction costs at times of financial crisis or major price corrections reveals that lower volatility, decreased trading volume, or plunge in prices did not accompany the introduction of higher costs. ${ }^{137}$

Finally, a transaction tax also has a paternalistic aspect to it. The assumption is that investors basing their trading on "noise" harm themselves and the society. Proponents of the tax, therefore, seek to offer them imperial protection: "[i]f we systematically use our freedom to buy and sell financial assets to our own disadvantage, it would be better for a wise and sympathetic central authority to limit that freedom." ${ }^{138}$ Skeptics scoff at this notion, observing that proponents bear a heavy burden in demonstrating a sound basis for "prohibiting or deterring voluntary commercial transactions

135 Stulz, supra note 104, at 305 (footnote omitted).

136 Grundfest \& Shoven, supra note I Io, at 4 I I ("Available evidence based on experience during the 1987 market crash, as well as on Sweden's experience with a transactions tax, also suggest that transaction taxes do not reduce market volatility."). A supporter of the tax, Professor Jeffrey Frankel, notes: "The historical experience with small taxes seems to be that there is no discernible effect on volatility. In some cases the volume of trading within the country is affected. But what the tax does usually do is raise a lot of money." Frankel, supro note 127 . Professor Frankel nonetheless endorses it because of this revenue-raising potential. Id.; see also Kiefer, supra note 63 , at 890 (noting that empirical evidence indicates that a transfer tax that reduces trading "would not affect volatility one way or the other"). But see Richard Roll, Price Volatility, International Market Links, and Their Implications for Regulatory Policies, $3 \mathrm{~J}$. Fin. Services. Res. 2 I I, 233-4l (1989). See generally Daniel B. Nelson, Commentary: Price Volatility, Intermational Market Links, and Their Implications for Regulatory Policies, 3 J. Fin. Services RES. 247 (1989) (presenting a critique of Roll's article).

137 Lynn Bai \&.Rujing Meng, Deterring "Double-Play" Manipulation In Financial Crisis: Increasing Transaction Cost as a Regulatory Tool, 35 N.C. J. INT'L L. \& CoM. Reg. 137, 163-64 (2009).

138 Mahoney, supra note 95, at 714 . 
between reasonably sophisticated parties who have ample alternatives and substantial access to relevant information." 139

\section{Capital Gains Tax}

\section{A. Preliminary Points}

The treatment of capital gains has been described as "a contentious question that appears to be a permanent fixture of tax policy debates." 140 The recurring question on what role capital gains tax rates should play in the short-termism debate clearly bears out th is observation. The U.S. policy regarding taxation of ordinary income and capital gains has been causally linked to short-termism. ${ }^{141}$ Tax policy changes from the 1970 s drastically reduced the differential between income tax and capital gains tax, thereby practically minimizing the incentive to hold stocks for the long term. ${ }^{142}$ Prior to these changes, investors were constrained to hold their stock for a longer period or risk the alternative of paying taxes on realized gains at the top marginal rate of 75 percent. ${ }^{143}$

Seeing that the capital gains tax policy can affect investment behavior, reform advocates consider higher taxes on profits from short-term investing as one of the tools that could be deployed to slow down investor short-termism. ${ }^{144}$ Capital gains tax reform could take a number of forms. One approach is to increase the applicable income tax rate for short-term capital gains from approximately 35 percent (for individuals and investing institutions with a high net worth) to a higher rate. ${ }^{145}$ Alternatively, the long-term rate could be decreased from the current rate of 15 percent. ${ }^{146}$ Reform may also be approached by increasing the short-term period

I 39 Id.; see also Kiefer, supra note 63, at 896 (arguing that taxes that discourage trading are inconsistent with the reasoning in economics that any activity that the actors are willing to pay for is valuable).

140 George R. Zodrow, Economic Analyses of Capital Gains Taxation: Realizations, Revenues, Efficiency and Equity, 48 TAX L. Rev. 419, 42 I (1993).

14 I See Tonello, supra note 30 , at 6.

142 Id.

143 Id.

144 Kelly \& White, supra note I 2, at 772; see also AsPEN INST., supra note I 8, at 3 (recommending a sliding scale capital gains tax reform "designed to discourage excessive share trading and encourage longer-term share ownership").

I45 The government taxes short-term capital gains as ordinary income. See I.R.C. § I (West $201 \mathrm{I}$ ); see also Gabaldon, Euphoric Market, supra note 87, at 281 (advocating "increasing rates on extremely short-term gains" to regulate stock trading behavior); Lowenstein, supra note 26 , at 12 (discussing a proposal to impose a one hundred percent tax on short term capital gains).

I46 I.R.C. § I. 
from 12 months to 24 months or more. ${ }^{147}$ Another approach that may be employed is a sliding-scale provision under which gains from short-term sales of stock are taxed at a high rate, but the rate decreases the longer the stocks are held by the owner ("holding period") prior to the sale. ${ }^{148}$ Instead of having two rates - short term and long term - what it would obtain is a steady decline in rates over time, "stretching beyond the one-year point that is presently the lowest rate at the federal level." ${ }^{149}$

\section{B. Arguments in Favor of Capital Gains Tax Reform}

The idea behind the capital gains tax reform proposal is to punish short term trading and encourage long term holding. ${ }^{150}$ Discussing the sliding scale form of capital gains tax, prominent corporate lawyer, Martin Lipton, poses the following argument:

The graduated tax would help shift the focus of institutional investors from the short to the long term, thereby harnessing the energy of a powerful group of professionals for improved corporate governance. A longer-term perspective will encourage institutional investors to bridge the gap between ownership and control by monitoring the ability of management to achieve the valuable long-term goals of expanding the enterprise and improving productivity. This focus, in turn, will increase the long-term value of corporate equity. ${ }^{151}$

A fairly recent call for an extension of the short term capital gains tax period to two years and imposition of a securities transaction tax was rationalized on the grounds that these changes will raise revenues and give a comparative advantage to those stockholders who operate as real investors,

147 If an asset is held for one year or less, the gain from its sale is classified as short-term. If it is held for longer than one year, the gain is classified as long-term. See id. § 1222(3); see also Leo E. Strine, Jr., Toward Common Sense and Common Ground? Reflections on the Shared Interests of Managers and Labor in a More Rational System of Corporate Governance, 33 J. CoRP. L. I, I 8 (2007) [hereinafter Strine, Toward Common Sense] (advocating an increase in the short-term period to two years as a way of encouraging long term investing).

148 Aleta G. Estreicher, Beyond Agency Costs: Managing the Corporation for the Long Term, 45 Rutgers L. Rev. 513, 601 (1993); see also Should the Government Promote or Protect New Technologies?, Fall Kan. J. L. \& Pub. Pol'y, Fall I994, at 37, 42 (Chimerine); Internal Revenue Serv., Sales and Other Dispositions of Assets: Publication 544, at 33 (2006) (defining holding period).

149 Jacoby, supra note 110, at 484 (2001); see also Martin Lipton, Comporate Governance in the Age of Finance Corporatism, 136 U. PA. L. Rev. 1, 64 (1987) [hereinafter Lipton, Finance Corporatism] (suggesting the implementation of a graduated tax).

150 Lawrence E. Mitchell, Business and Short Termism - Why Investor Taxation is the Solution, ETHICAL CORP. (Aug. I I 2006), http://www.ethicalcorp.com/content/business-and-shorttermism-why-investor-taxation-solution [hereinafter, Mitchell, Investor Taxation].

151 Lipton, Finance Corporatism, supra note 149, at 64. 
as opposed to those who behave like gamblers. ${ }^{152}$ Similarly, since a capital gains tax is expected to reduce liquidity, it is considered an antidote to the tendency of some shareholders to exit the firm easily and, by extension; a device to encourage long-term investing. ${ }^{153}$ One commentator confidently posits that a higher tax on capital gains based on length of holding "would work dramatic behavioral changes in securities markets, especially among short-term speculators such as arbitrageurs." 154

\section{Arguments Against Higher Capital Gains Tax}

First, in response to the immediately preceding point in support of higher capital gains tax for some short-term investors, the idea that arbitrageurs are bad and need to be inhibited in their work is open to question. ${ }^{155}$ In fact, one argument against securities and capital gains taxes is that such taxes would impose additional costs on arbitrageurs, who by nature are also short-term speculators, thereby deterring them from correcting mispricings of stocks. ${ }^{156}$

Not surprisingly, the proposed capital gains tax reform has attracted a number of strong criticisms. One commentator notes that the reduction of the capital gains tax rate in 2003 had the salutary effect of improving liquidity in the market, while doubling capital gains revenues for the federal government from $\$ 269$ billion in 2002 to $\$ 539$ billion in 2005 . ${ }^{157}$

I52 Strine, Toward Common Sense, supra note 147 , at I 8.

153 See Estreicher, supra note 148 , at 600-0I.

I 54 Id. at 601.

I55 See Erik F. Gerding, Laws Against Bubbles: An Experimental-Asset-Market Approach to Analyzing Financial Regulation, 2007 Wis. L. REv. 977, 981 ("Economic and legal scholars have long seen arbitrage as a cure for speculative mispricings and as a means to short-circuit asset-price bubbles," leading to successful calls for removal of federal securities regulation that hampered short sales) (footnotes omitted); see also id. at $98 \mathrm{I}$ n.12 ("Arbitrage means investment trades that exploit a perceived short-term mispricing of an asset. For example, if an arbitrageur believes a certain stock is overvalued, he or she sells that stock short (i.e., borrows shares of that stock and then sells them). The arbitrageur profits if the stock price declines from the amount owed the lender of the stock (but loses if the price rises). Arbitrageurs hedge their risks when entering into short sales by simultaneously buying a close substitute of the stock.").

I56 Id. at 1027; see also Andrei Shleifer \& Robert W. Vishny, The New Theory of the Firm: Equilibrium Short Horizons of Investors and Firms, AM. ECON. REv., May 1990, at 148, 148-53 (1990), available at http://www.economics.harvard.edu/faculty/shleifer/files/equilibrium.pdf (stating that the "short horizons of arbitrageurs lead to short horizons of corporate managers" but also adding that "[a]rbitrage generally serves the useful social function of bringing asset prices closer to fundamental values"). See generally Jeremy C. Stein, Presidential Address: Sophisticated Investors and Market Efficiency, 64 J. FIN. 15 I 7 (2009), available at http://www.economics.harvard.edu/faculty/stein/files/presidential-address-jf-final.pdf (noting the difficulty in determining whether arbitrage contributes to greater market efficiency).

I57 John F. Olson, Reflections on a Visit to Leo Strine's Peaceable Kingdom, 33 J. CoRP. L. 73 79 (2007). 
Moreover, there is the concern that using negative tax consequences to deter. investors from selling their positions amounts to artificially interfering with market discipline instead of allowing companies with good management to prosper. ${ }^{158}$

Using a preferential rate for capital gains relative to income tax to encourage long-term investing on the expectation that it would in turn engender a long-term perspective by management has been assailed; the view is that it would be ineffective regardless of whether investors behave rationally or irrationally. ${ }^{159}$ In a stock market in which investors behave rationally, every stockholder, including one that trades with a short-term horizon, has a vested interest in seeing management maximize long-term profits on the understanding that a high price for any company's stock can hardly exist if buyers do not believe that the company's prospects for longrun profitability are good. ${ }^{160}$ Conversely, irrational investors, by definition, are unlikely to take advantage of the capital gains preference to invest long-term. ${ }^{161}$

Higher capital gains tax for short-term trading and the resulting decrease in liquidity raise some concerns, particularly as it compels investors whose securities have appreciated in value to hold on to securities for a little longer to satisfy the long-term requirement, even when they know that the price will fall during the remainder of the holding period. ${ }^{162}$ Essentially, investors are given an incentive to hold on to less profitable assets. Not only are older investments that are no longer as profitable as newer opportunities kept longer, the ability of newer investments to attract capital is reduced, perhaps to a suboptimal level. ${ }^{163}$.

Such a tax, as with the securities tax, also runs into the additional objection that it punishes innocent short-term investors who are selling because their economic position, rather than market speculation, so dictates.

${ }_{15} 8$ Id.

I59 James R. Repetti, The Misuse of Tax Incentives to Align Management-Shareholder Interests, I9 CARDozo L. Rev. 697, 713-14 (1997) [hereinafter Repetti, Tax Incentives].

I6o Id; see also Black, Watching Agents, supra note 24, at 863 ("In a reasonably efficient capital market, even an investor who plans to sell next month must care about long-term value, because buyers will have a longer horizon.").

I61 Repetti, Tax Incentives, supra note 159, at 714; James R. Repetti, Long-Term Capital Gains, the Long-Term Investment Perspective, and Corporate Productivity, 49 TAx NoTes 85, 90-91 (1990) ("[I]f the market is in fact controlled by irrational investors, then holding period requirements will be ineffective ...."); Repetti, Tax Law, supra note 30, at 627-30.

162 See Mark L. Louie, Note, Realizing Appreciation Without Sale: Accrual Taxation of Capital Gains on Marketable Securities, 34 Stan. L. Rev. 857, 872 n.64 (1982).

163 Id. at 864. The effect is similar to the "lock-in" phenomenon. Id. at 872 n.64. The phenomenon, considered the most potent argument against capital gains taxation, refers to the tendency of investors to defer the sale of appreciated assets since no taxes are due until they realize the gains from the assets, consequently depriving themselves of needed cash or ability to take advantage of available investment opportunities. See $i d$. at 864; David Carris, Capital Gains Taxation: A Full Circle? 14 T. Marshall L. Rev. 43, 53-54 (1989). 
One advocate of taxing short-term capital gains at a higher rate tempers the call with a suggestion for exemption of some short-term trades, including those executed by market makers and exchange specialists. ${ }^{164}$ Sale of stocks when holders are left with no option, an example of which is a forced sale following a merger, might also be excluded from the tax. ${ }^{165}$ Another proponent suggests addressing the injustice by granting exemptions to those who demonstrate that economic hardship compelled them to sell. ${ }^{166}$ The burdens that such a demonstration would impose on investors and the implementation challenges that it would pose for bureaucrats lessen the palatability of the proposal. In summary, there is little to inspire confidence that the transaction and capital gains taxes will accomplish the stated objectives. ${ }^{167}$

\section{LOYALTY Dividend}

\section{A. Preliminary Points}

Dividends are distributions made to shareholders qua shareholders out of the corporation's surplus or net profits. ${ }^{168}$ It is a basic way for shareholders

I64 Estreicher, supra note 148, at $60 \mathrm{I}$.

165 See id.

I66 Mitchell, Investor Taxation, supra note I50.

167 One commentator explains as follows:

An array of evidence suggests that transaction and capital-gains taxes will have mixed results in preventing bubbles. In one experimental asset market, a moderate transaction tax did not eliminate bubbles or reduce their duration, but it did reduce the amplitude of a bubble. Oddly, this transaction tax increased the turnover of shares for traders inexperienced with the experiments. In another experiment, a fifty-percent-capital-gains tax likewise did not reduce the tendency of bubbles to occur.

This experimental evidence accords with the observation by one economist that real-estate markets, which have higher transaction costs than stock markets, still experience bubbles. Moreover, countries that impose higher transaction costs on trades do not seem to enjoy less stock-market volatility. Of course, at a highenough rate, transaction taxes will deter speculation but at the potential cost of choking-off liquidity in the market.

Gerding, supra note 155 , at 1026-27 (footnotes omitted).

168 See Franklin A. Gevurtz, Corporation Law 153 (2000) ('“Dividends' is the common term for distributions from a corporation to its shareholders by virtue of their position as shareholders."); 18 C.J.S. Corporations $\$ 360$ (2011) (“The term 'dividend,' as applied to corporate stock, may be defined as that portion of the profits and surplus funds of a corporation which has been actually set apart, by a valid act of the corporation, for distribution among the stockholders according to their respective interests, in such a sense as to become segregated from the property of the corporation, and to become the property of the stockholders distributively. The term 'dividend' may, more simply, be defined as a payment to stockholders as a return upon their investment." (footnotes omitted)); see also Margaret M. Blair, Reforming Corporate Governance: What History Can Teach Us, I Berkeley Bus. L.J. I, 26 n.89 (2004) ("Dividends may only be paid out of surplus, or if there is no surplus, out of net profits for the most recent two fiscal years, but any decision to pay dividends is solely the prerogative of directors."). 
to get a return on their investment. ${ }^{169}$ Nonetheless, shareholders are not entitled to dividend payments unless the Board declares them. ${ }^{170}$ Therefore, barring exceptional circumstances, ${ }^{171}$ the declaration of dividends is entirely at the discretion of the directors. ${ }^{172}$ The proposed loyalty dividends are additional to the regular dividends that shareholders receive when declared by the Board. ${ }^{173}$ Accordingly, the loyalty dividends would not be declared without a prior declaration of the regular dividends. ${ }^{174}$

A prominent proponent of loyalty dividends, Peter Butler, has described the loyalty dividend as probably the most interesting proposal for redressing the balance between short-termism and long-run value. ${ }^{175}$ He explains that the dividends would go only to those stockholders who do not sell or lend their stock for a stated period. ${ }^{176}$ Directors would propose the dividends through a resolution at the company's annual meeting, ensuring that it is of sufficient size to accomplish its goal without creating

I69 Douglas K. Moll; Shareholder Oppression B Dividend Policy in the Close Corporation, 60 WASH. \& LEE L. Rev. 841, 842 (2003) ("The receipt of a dividend is perhaps the most basic method by which a shareholder earns a return on her investment in a corporation.").

I70 Blair, supra note I68, at $26 \mathrm{n} .89$ ("Under case law dating back to 1868 , shareholders have not had the legal right to receive any dividend at all unless it was declared by directors.").

I 1 There are several examples of exceptional circumstances, namely, where there have been huge accumulations of profits. See, e.g., Dodge v. Ford Motor Co., 170 N.W. 668, 685 (Mich. 1919) (affirming lower court's decree requiring distribution of a special dividend and holding board of directors refusal to declare extra dividends was arbitrary where a substantial surplus remained after paying approved plant expansion and improvement costs and very large annual profits were reasonably expected); Gottfried v. Gottfried, 73 N.Y.S.2d 692, 695 (Sup. Ct. 1947) (stating the principle that when an adequate surplus is available, directors must not act in bad faith in failing to pay dividends); Patton v. Nicholas, 279 S.W.2d 848, 85354 (Tex. 1955) (holding minority shareholders entitled to remedy for "malicious suppression of dividends" when, in the face of substantial surplus accumulation, the majority shareholder exercised control over the board to prevent any dividends being paid with the intention of lowering the market value of minority shares).

172 See Daniel R. Fischel, The Law and Economics of Dividend Policy, 67 VA. L. Rev. 699, 700 ( $198 \mathrm{I}$ ) ("[C]urrent legal rules giving management virtually unlimited discretion in making the dividend decision maximize shareholder welfare [in public corporations].").

I 73 See, e.g., Notice of Meeting Constituting Notice of Convocation to the Shareholders of Lafarge I-3 (Mar. 29, 2010), http://www.lafarge.com/o3292010-publication_financeBALO_AGO_20 Io-uk.pdf (proposing, for the 2010 Ordinary Shareholders Meeting, a regular dividend of 2 Euros per share and a loyalty dividend of 2.2 Euros per share).

174 See Aaron Gray-Block, DSM Loyalty Div Scheme Wins Backing from European Corporate Governance Watchdog, ABC Money (United Kingdom), Mar. 14, 2007, http://www.abcmoney. co.uk/news/14200739202.htm (noting that a proposed loyalty dividend would not be at the expense of regular dividends).

I 75 Peter Butler, Chief Executive, Governance for Owners, Address to the ICGN Annual Conference in Washington 5 (July 2006), htcp:/www.governanceforowners.com/goss/ think-piece/2006 (follow "Peter Butler's address to the ICGN Annual Conference in Washington Hedge funds - Download PDF" hyperlink).

I $76 \mathrm{Id}$. 
additional problems for the company or shareholders. ${ }^{177}$ The rationale for the loyalty dividend, according to Butler, is as financial inducement to enable shareholders to defray the extensive cost associated with the proper exercise of their "democratic" responsibilities within the corporation. ${ }^{178}$ Unfortunately, these costs are likely to be borne only by long-term holders, as opposed to most short-term investors who, by the nature of their temporal commitment, lack an interest in such responsibilities. ${ }^{179}$ The "extra dividend would be a payment for loyalty and would help to off-set the additional costs of being a responsible long-term owner. A dividend differential of less than $5 \%$, say $10-15$ basis points, would be sufficient to change behaviour in the market." 180

\section{B. Arguments in Favor of Loyalty Dividends}

Scholars have argued that regular dividends help bridge the monitoring gap, because the expectation of dividends provides an incentive for shareholders to engage in more frequent and effective monitoring of managerial conduct. ${ }^{181} A$ fortiori, shareholders who expect an extra dividend may be galvanized to keep a close eye on management to ensure that the corporation is managed in way that ensures maximization of long-run value, given that it is the only way to assure continued payment of the loyalty dividends.

The notion that stockholders generally reserve no loyalty for the companies whose stock they hold is well-founded. ${ }^{182}$ This observation is even truer in the case of short-term shareholders whose primary focus on immediate gains leads to a weakened attachment to their companies. A loyalty dividend is a way of rewarding those shareholders that have evinced an appreciable level of loyalty, while encouraging other shareholders to make a similar demonstration. Apart from serving to incentivize shareholders to keep their shares for a longer term, loyalty dividends also aim to improve investor relations by creating an opportunity for more direct communication between shareholders and the firm's management. ${ }^{183}$ Accordingly, these dividends could be viewed as a subsidy to promote the

\section{Id.}

$178 \mathrm{Id}$.

179 See id.

I 80 Id.

181 See Robert Charles Clark, Corporate Law § i4. I, at 598-60o (1986).

182 Kent Greenfield, Reclaiming Corporate Law in a New Gilded Age, 2 HaRv. L. \& Pol'y Rev. I, 9 (2008); see also Homer Kripke, The SEC, Corporate Governance, and the Real Issues, 36 Bus. LAw. 173, 177 (1981) (stating that the average shareholder sees himself as an investor "free to move into and out of the corporation without loyalty ..."). .

i83 Proxy Voting Guidelines, Tridos Bank 3 (2010), available at http://wwwitriodos. com/downloads/research/proxy_voting_guidelines_2oro.pdf. 
engagement of long-term shareholders with the corporate management, instead of "voting with their feet" when they disagree with the direction of the corporation. ${ }^{184}$

While supporters of this proposal may see this subsidy as a justified fillip to boost long-term shareholder activism, opponents may also justifiably view it as tilting the shareholder playing field against hedge funds, which are willing on their own to spend money to advance their goals. ${ }^{185}$ Besides, the dividends could be seen as a form of perverse incentive that motivates shareholders to engage in actions without bearing the cost. As many economists would preach, "parties bearing the full cost of their actions make better decisions than those that do not." ${ }^{186}$ On the other hand, it also follows that what gets compensated is what gets accomplished. ${ }^{187}$ Thus, without the subsidy, long-term shareholders are unlikely to take the needed steps, as current experience amply demonstrates. ${ }^{188}$ Proponents seem to be propelled by this recognition in making the case for loyalty dividends. ${ }^{189}$

The attractiveness of this proposal lies in the fact that it can be implemented without recourse to the regulatory apparatus of the state. Thus, companies may adopt it on their own initiative and structure it to fit their particular circumstances. ${ }^{190}$ A partial explanation for the growing interest in the concept of loyalty dividend is the opportunity it provides management to have greater access to information relating to the ownership of the company's stock. Usually, the introduction of the dividend requires

184 See Thomas W. Briggs, Corporate Governance and the New Hedge Fund Activism: An Empirical Analysis, 32 J. CoRP. L. 681, 712 (2007) ("The shareholder primacists' proposed solutions to this problem are downright toxic to hedge funds. The main issue is that recently proposed solutions amount to a subsidy for these other shareholders who either cannot or will not pay their own way....")

$185 \mathrm{Id}$.

186 Roberta Romano, Less is More: Making Institutional Investor Activism a Valued Mechanism of Corporate Governance, 18 YALE J. ON REG. 174, 230 (200I).

187 See N. Gregory Mankiw, Crisis Economics, NaT'L AfF., Summer 2010, at 2 I, jo, available at http://nationalaffairs.com/doclib/20100614_Mankiw_Web.pdf (stating that certain "changes in incentives can influence behavior").

I 88 See Thomas W. Briggs, Corporate Governance and the New Hedge Fund Activism: An Empirical Analysis, 32 J. CoRP. L. 681, 7 10-1 I (2007) (stating that shareholders generally do not have sufficient incentives to participate actively in corporate affairs); John Pound, The Rise of the Political Model of Corporate Governance and Corporate Control, 68 N.Y.U. L. Rev. I003, I041-42 (I993) (stating that shareholders will monitor when it is in their economic interest to do so). See generally Adolf A. Berle \& Gardiner C. Means, The Modern Corporation \& Private Property (Ioth ed. 2009) (examining the divorce of ownership and control in the modern corporation).

I89 See Butler, supra note 175 , at 5 .

I90 Id. ("Different companies can experiment with a different framework."). This is very important. As some scholars have noted, "to the extent short-termism generates a problem, adaptive devices adopted by corporations are a better way to address it than regulation." $\mathrm{Ka}$ han \& Rock, Hedge Funds, supro note 21 , at 1027. 
the registration of shares with the company by participating shareholders. ${ }^{191}$ The insight that the company obtains in return for the loyalty dividends provides it with advance notice of potential sources of threatening maneuvers. According to some observers, the shareholding registration requirement "would avoid situations of creeping control and enable companies to have more direct contact with its investors - and know the scale of investors' shareholdings more readily." ${ }^{192}$

\section{Arguments Against Loyalty Dividends}

The loyalty dividend is not without its fair share of criticisms. One concern is that payment of extra dividends would shift resources from the corporation to shareholders, such that the corporation may have to resort to the capital markets to finance new ventures or expansion projects. ${ }^{193}$ So, it raises questions about whether or not the interests of shareholders would be better served by having the corporation re-invest the funds and create more value or whether the shareholders are sufficiently capable of doing more with the funds than the company. ${ }^{194}$ However, strong arguments support dividend payments because of the disciplining effect it has on managers and the comparative advantage that it ultimately gives shareholders vis-à-vis debt holders. ${ }^{195}$

A particularly strong objection to a loyalty dividend is that its adoption would undermine the principle of equal treatment of all similarly situated shares. ${ }^{196}$ Indeed, instituting loyalty dividends in some places or for certain

igi See Hermes Inv. Mgmt. Ltd., Position Paper: Hermes' Approach to Loyalty DiviDENDS I (2011) (on file with author).

192 Id.

193 This argument has been raised in connection with regular dividends but applies, perhaps with greater force, in the context of extra dividends like loyalty dividends. See Frank H. Easterbrook, The Race for the Bottom in Corporate Governance, 95 VA. L. Rev. 685, 689 (2009).

194 "At the end of the day, you have to ask yourself, can you personally invest $\$ 70$ billion better than your stockholders." Robert A. Guth \& Scott Thurm, Microsoft to Dole out Its'Cash Hoard, Wal.L ST. J., July 2 I, 2004, at AI (quoting Jonathan Schwartz, then president of Sun Microsystems); see also Victor Brudney, Dividends, Discretion, and Disclosure, 66 VA. L. Rev. 85, 96-97 (1980) ("[T]here is evidence to suggest a systematic stockholder preference for individual investor power to make the reinvestment decisions ...."); Marsha Cope Huie, Antitrust and Corporate Dividend Policy: Revising Dividend Payment Policies to Empower Shareholders to Curb Mergers and Acquisitions, 25 ST. MARY's L.J. 243, 247 ( I993) (criticizing the nondeclaration of corporate stockholder dividends); of. Daniel J. Morrissey, Another Look at the Law of Dividends, 54 U. KaN. L. Rev. 449, 486 (2006) ("When investors are denied dividends, however, the analysis has to focus on their ultimate welfare. Will they be sufficiently compensated for their privation by returns from the earning that their firm is reinvesting?").

195 See Frank H. Easterbrook, Two Agency-Cost Explanations of Dividends, 74 AM. EcoN. Rev. 650, 653, 655 ( 1984); Morrissey, supra note 194, at 481 .

I 96 Hermes Inv. Mgmt. LTD., supra note 191, at I "The fundamental argument against such loyalty dividends is that they breach the principle of equality of rights and treatment 
companies will require legislative changes. ${ }^{197}$ The equal treatment of shares of the same class is considered a bedrock principle of American corporate culture. ${ }^{198}$ However, Delaware law only requires fair, but not necessarily equal, treatment of all shares by the directors. ${ }^{199}$ Where there is a corporate benefit behind the treatment, the fairness requirement is satisfied..$^{200}$ An argument could be made that unequal treatment is permissible in circumstances where the object is the protection of the company and shareholders from serious damage by other shareholders. It is not uncommon in an organizational setting, where the quick exit of members increases the burden on the remaining members or otherwise adversely affects the continued existence of the organization, to introduce incentives to encourage long-term commitment, such.as senior pricing discounts. ${ }^{201}$ It would appear that the loyalty dividend falls squarely in this category.

Moreover, supporters would argue that the loyalty dividend is not dissimilar from the bonuses and discounts that companies provide to their long-term customers in appreciation of their loyalty. ${ }^{202}$ In any case, possible

between members of a single class of shares. In effect, those shareholders which invested in the short-term or chose not to register their shares would be subsidising the investment of others."); Cornelia Messing, DSM Faces Possible Action from Franklin Mutual over Loyalty Dividend-Report, ABC MoneY, Feb. 23, 2007, http://www.abcmoney.co.uk/news/23200728285. htm\#.

197 See, e.g., L. Reed Walton, 2008 Proxy Preview: Canada, ISS Governance (Feb. I2, 2008, I I:4 I AM), http://blog.issgovernance.com/gov/2008/02/2008-proxy-preview-canadasubmitted-by-l-reed-walton-publications.html (stating that a loyalty dividend is not "possible in actual practice as the law requires equal treatment of common shareholders of Canadian banks.").

198 See Douglas M. Branson, Corporate Social Responsibility Redux, 76 Tul. L. Rev. I207, 12 I 2 (2002); Shaun Martin \& Frank Partnoy, Encumbered Shares, 2005 U. ILl. L. Rev. 775, 775 ("Corporate law treats shares equally.").

199 Douglas M. Branson, The Very Uncertain Prospect of "Global" Convergence in Corporate Governance, 34 CoRNELL INT'L L.J. 321 , 330 n.4I (200I) ("Under the substantive law of Delaware, corporate directors are free to discriminate among shares of the same class, including minority held shares, because Delaware requires only 'fair' treatment, not 'equal' treatment of shares." (citing Nixon v. Blackwell, 626 A.2d I366 (Del. 1993))); $f f$. CAL. Corp. Code § I IoI (West 1999 \& Supp. 2011 ) (prohibiting unequal treatment of shares of the same class).

200 See James D. Cox, Equal Treatment for Shareholders: An Essay, 19 Cardozo L. Rev. 6I 5 , 617 (1997).

20I Patrick Rey \& Jean Tirole, Loyalty and Investment in Cooperatives 4-5 (Institut D'Ėconomie Industrielle, Working Paper, 2000), http:/idei.fr/doc/by/rey/loyalty.pdf.

202 See Tom Powdrill, Exit, Voice and Loyalty (Dividends), Labour \& CaPITal Blog (Oct. 12, 2009), http://abourandcapital.blogspot.com/2009/1o/exit-voice-and-loyalty-dividends. html. 
responses to the equal treatment objection include amending existing corporate statutes and charters to accommodate loyalty dividends.

The loyalty dividend policy proposed by Dutch chemical company, Royal DSM in early 2007, presents a useful case study. ${ }^{203}$ Under DSM's loyalty dividend plan, shareholders register their shares and also furnish additional details. ${ }^{204}$ Holding the shares continuously for 3 years, entitles the shareholder to a $10 \%$ additional dividend. ${ }^{205}$ The policy was challenged at the Dutch Enterprise Chamber by one of its shareholders, a hedge fund, that argued that the loyalty dividend violates the equality of rights of all shares under the Dutch Civil Code. ${ }^{206}$ The Enterprise Chamber agreed with the hedge fund, but was overruled by the Supreme Court of the Netherlands, which arrived at its decision without resolving the issue of the legality of the loyalty dividend policy. ${ }^{207}$ Nevertheless, some commentators agree with the argument of the Dutch Advocate General at the Supreme Court that the policy should be upheld on the basis that, even though it would result in differential treatment of similarly situated shareholders, it is justified. ${ }^{208}$ Dutch jurisprudence already permits deviation from the equality principle if reasonable and objective grounds exist. ${ }^{209}$ According to the Advocate General, such a ground exists when the objective of the loyalty policy supersedes the short-term goals of shareholders. ${ }^{210}$

Notwithstanding the merits of the above proposals, it is unlikely that they suffice as antidotes to short-termism. Because of the Wall Street Rule, shareholders remain free to sell easily. ${ }^{211}$ What is needed is a critical mass of shareholders that are firmly committed to holding a corporation's stock for the long haul. ${ }^{212}$ However, the chances of getting that core of shareholders

203 Royal DSM N.V., Reasons and Structure for the Loyalty Dividend, (Dec. I9, 2006, 8:15 AM), http://www.dsm.com/en_US/cworld/public/media/pages/press-releases/63_o6_dsm_ opens_pre_registration.jsp.

204 Id.; see also Ferdinand Mason \& Tim Carapiet, Loyalty Dividends: DSM and the Legal Debate over Shareholder Incentives, IN-HouSE Law., 80, May 2008, http://www.boekel.com/media/9321 7/in-house\%2olawyer\% 20may\%202008\%20mason\%2ocarapiet.pdf.

205 Mason \& Carapiet, supra note 204.

$206 \mathrm{Id}$.

207 Id. at $80-81$.

208 Id. at $8 \mathrm{I}$.

209 Id.

2 ro Id.; Ferdinand Mason and Tim Carapiet add that loyal shareholders can "serve as a defensive tool against short term opportunism, as it requires a financial shareholder to be rather creative to gain control over a company." Id.

211 . See Lowenstein, supra note 26, at 12 (arguing that even a one hundred percent short term capital gains tax will not overcome short-termism because of the Wall Street Rule).

212 See John H. Matheson \& Brent A. Olson, Corporate Law and the Longterm Shareholder Model of Corporate Governance, 76 MiNN. L. REv. I313, 1371-72 (1992) (observing that a core base of long-term investors is vital to a corporation's implementation of a long-term mandate); Williams \& Conley, supra note 56, at 537 ("We suggest that the greater concentration of longer-term investors in the [United Kingdom] is one factor that has led to more 
are miniscule without a change in the structure of the corporation to really empower shareholders in return for their loyalty. ${ }^{213}$ For an investor, the incentive that loyalty dividends present has to match the opportunities foregone both from financial and non-financial angles. If short-termists feel more empowered by not tying themselves down to any particular investment, and thereby giving themselves leverage with corporate managers, an acceptable alternative would have to replace that sense or reality of empowerment. Likewise, if the financial returns of high turnover trading far surpass the benefit of a loyalty dividend, the dividend cannot be an effective alternative. Perhaps, the economic allure of the dividends may be further strengthened by making them tax-free, unlike regular dividends. ${ }^{214}$ This approach would parallel the exclusion from dividend

attention being paid in that market to longer-term social and environmental risks."); see also Alison Ather'ton et al., Inst. for Sustainable Futures, Solutions to Short-Termism in - THE FinANCE SECTOR 14 (2007), available at http://www.isf.uts.edu.au/publications/athertonetal2007solutionstoshorttermism.pdf ("[C]ompanies should seek out those investors who will form a long-term shareholder base.").

213 LowENSTEIN, supra note 26, at 12, 208-10 (stating that a "major hurdle is that the shareholders have never had access to the nominating procedures for directors or the proxy machinery, except by a we-they confrontation that fund managers are understandably reluctant to undertake" and arguing for shareholder power to nominate and elect a percentage of directors that would be answerable to them). Recent legislative and regulatory changes have provided a framework for shareholder access to the proxy machinery. See Press Release, U.S. Sec. \& Exch. Comm'n, SEC Adopts New Measures to Facilitate Director Nominations by Shareholders (Aug. 25, 2010), available at http://www.sec.gov/news/press/2010/2010-1 55.htm. For various reactions to the adoption of the proxy access regulations, see Stephen Bainbridge, SEC Adopts Proxy Access, ProfessorBainbridge.com (Aug. 25, 2010, 1:39, PM), http://www. professorbainbridge.com/professorbainbridgecom $/ 2010 / 08 / \mathrm{sec-adopts-proxy-access.html;}$ Lucian Bebchuk \& Scott Hirst, Proxy Access Is In, Harv. L. Sch. Forum on Corp. GoverNANCE \& Fin. Reg. (Aug. 25, 2010 , i I :20 AM), http://blogs.law.harvard.edu/corpgov/2010/08/25/ proxy-access-is-in/. The Conglomerate Blog organized a forum on proxy access that contains divergent responses to the new regulations. See Erik Gerding, Proxy Access Forum: It's a Wrap, Conglomerate (Aug. 30, 2010) http://www.theconglomerate.org/forum-proxy-access/.

2 I 4 Currently, regular dividends are taxed at a rate of 15 percent. See I.R.C. $\$$ I(h)(C) (West 201 I ). At times, the rate has been much higher than that, as dividends have previously been treated as ordinary income for tax purposes. See Steven A. Bank, Dividends and Tax Policy in the Long Run, 2007 U. ILL. L. REv. 533, 537-38 (noting that before the change in 2003, individual taxpayers paid taxes on dividends at a marginal rate that went as high as 38.6 percent for highest income earners); James F. Loebl, Qualified Dividends: Do They Avoid Double Taxation or Do They Double Shareholders' Benefit?, 56 Depaul L. REv. 1 139, 139 (2007) (stating that prior to 2003 individuals reported their dividends as ordinary income and paid tax on the dividends at their marginal tax rate; but legislation signed by President George W. Bush in 2003 and 2006 limited the top marginal tax rate on dividends received from domestic corporations to fifteen percent); Note, Taxing Private Equity Carried Interest Using an Incentive Stock Option Analogy, I 2 I HARv. L. Rev. 846, 864 (2008) ("Since 2003, individual taxpayers have paid the lower long-term capital gains rate when they receive so-called 'qualified dividends,' a category that includes dividends from domestic corporations."). The Obama Adminstration has retained the Bush tax provisions under a compromise brokered in late 2010. See Sabrina Eaton, Breaking Down the Tax Agreement, Plain Dealer (Cleveland, Ohio), Dec. 8, 2010, at A7. 
taxation that corporate entities who were shareholders in other corporations enjoyed in the early twentieth century. ${ }^{215}$ However, advocating for taxfree treatment carries the burden of resorting to the public sphere for the requisite regulatory intervention, thereby taking away one of the most attractive features of the loyalty dividend. Finally, in view of the demerits identified with the three proposals and the harm they could occasion, it may be a more fruitful endeavor to focus on positioning management to resist investor short-țerm pressure. In fact, the management side of the equation may deserve more serious consideration. Part $V$ outlines a pathway that frees managers to manage for the long term.

\section{Long-Term Management}

\section{A. Managing for the Long-term}

One common ground shared by virtually everyone that is involved in this debate is the need to preserve the existence of every corporation for as long as possible. The problem is developing a plan that emphasizes longterm performance, subordinating to it anything else to the contrary. One commentator speaks for this consensus and the accompanying dilemma in the following words:

The idea that management's primary responsibility is to maximize long-term shareholder value is widely accepted in principle but imperfectly implemented in practice. Maximizing long-term value means that management's primary commitment is to continuing shareholders rather than to day traders, momentum investors, and other short-term-oriented market players. To maximize value to continuing shareholders, managers must develop and effectively execute strategies that maximize the company's long-term cash flow potential. ${ }^{216}$

One point that emanates from this observation is that short-termism cannot be addressed by over-emphasizing investor contribution to the problem. The management side of the equation, including the board

215 George Mundstock, Taxation of Intercorporate Dividends Under an Unintegrated Regime, 44 TAX L. Rev. I, 4-6 (1988) (stating that under a I909 Act, dividends that a corporation received from another corporation were not subject to taxation).

2 I6 Rappaport, supra note 6, at 69. 
of directors and senior officers of the corporation, deserves equal, if not greater, attention.

\section{B. Managerial Short-termism}

While it may be true that managers sometimes respond to market or investor short-term pressure, managers may also be independently myopic. ${ }^{217}$ Like investor short-termism, there has also been skepticism about managerial short-termism fueled by the efficient capital market hypothesis. ${ }^{218}$ It did not take long, however, for the counter-contention to develop with the effective demonstration that myopic behavior on the part of corporate managers who care about stock prices was possible even when the stock market is fully efficient. ${ }^{219}$ For instance, "managers might rationally behave myopically as a result of a sort of prisoner's dilemma, in which they are trapped in myopic behavior even if they know that the market would be efficient in equilibrium." ${ }^{220}$ Moreover, in expectation of earlier exit or retirement from the company, managers may have little motivation to pursue goals that have a maturity point in the distant future. ${ }^{221}$ Also, compensation through stocks and stock options could propel managers to inflate or otherwise manipulate financial information to prop up stock prices in the short-term for the benefit of the mangers who are ready to sell or exercise the options. ${ }^{222}$ Interestingly, short horizon investors are likely to support shorter vesting periods for stock options given to executives, knowing that it could incentivize executives to adopt an outlook that is favorable in the short-term and therefore beneficial to the short-termist investors, even if unfavorable to the corporation in the long run. ${ }^{223}$

Based on the foregoing, it is not surprising that scholarly attention has also gravitated in the direction of managerial short-termism. Scholars

217 David I. Walker, The Challenge of Improving the Long-Term Focus of Executive Pay, $5 \mathbf{I}$ B.C. L. Rev. 435, 441-42 (2010) (outlining reasons why managers would choose to be myopic).

218 See Jeremy C. Stein, Efficient Capital Markets, Inefficient Firms: A Model of Myopic Corporate Behavior, 104 Q. J. EcoN. 655, 655 (1989) (discussing one variant of the efficient capital market argument: "since it is unlikely that the market can be systematically fooled by inflated earnings, managers will only lower stock prices by undertaking actions that are not in the best long-run interests of their companies; [therefore,] managers who are concerned with high stock prices will not behave myopically") [hereinafter Stein, Myopic Corporate Behavior].

219 Seeid.

220 Walker, supra note 2 I 7 , at 441 ; see Stein, Myopic Corporate Behavior, supra note 2 I 8 , at $656-6 \mathrm{r}$.

221 Walker, supra note 217 , at 457.

222 Umakanth Varottil, Evolution and Effectiveness of Independent Directors in Indian Corporate Governance, 6 Hastings Bus. L.J. 28I, 302 (2010).

223 See Kenneth R. Davis, Taking Stock - Salary and Options Too: The Looting of Corporate America, 69 MD. L. REv. 419, 447 (2010) ("A reckless corporate strategy, in the short term, may increase the market price of a stock, which is what short-term institutional investors need to cash out with a profit. Once out, they have no concern if the risky strategy later backfires and 
have, among others, proposed reform of executive compensation practices and expansion of director fiduciary duties. As earlier noted, compensating corporate managers through stocks and stock options may induce shortterm emphasis on their part. ${ }^{224}$ Proposals to reform executive pay proceeds on the logic that ensuring that managers do not run their companies with a short-term focus may require that equity-based compensation take the form of restricted stock and longer holding periods for stocks and stock options. ${ }^{225}$ Interestingly, the push toward compensating corporate managers with equity started with the noble intention of reducing the agency costs occasioned by the separation of ownership and control. ${ }^{226}$ The assumption is that stock ownership or stock-based compensation aligns the interests of managers and stockholders, thus propelling managers to act to maximize shareholder value and corporate long-run growth. ${ }^{227}$ Perhaps, in a classic

the stock price collapses. Thus, short-term institutional investors will not object to the immediate vesting of stock options, a favorite compensation arrangement which encourages reckless corporate decisionmaking." (footnote omitted)); Karl S. Okamoto \& Douglas O. Edwards, Risk Taking, 32 Cardozo L. Rev. 159, 187 \& nn.132-33 (20 10).

224 See Lucian A. Bebchuk \& Jesse M. Fried, Paying for Long-Term Performance, ${ }_{5} 8$ U. PA. L. Rev. 1915, 1916-17 (2010); Patrick Bolton et al., Executive Compensation and Short-Termist Behaviour in Speculative Markets, 73 Rev. Econ. Stud. 577, 579 (2006).

225 See Walker, supra note 217 , at 455-56; see also Lawrence E. Mitchell, Response, The Partner-Manager: Some Thoughts on Bebchuk and Fried, I59 U. PA. L. Rev. PENNumbra 59, 64 (2010), http://www.pennumbra.com/responses/response.php?rid=93 (questioning the adequacy of restraints alone, without altering incentives, in addressing the problems occasioned by the current structure of executive compensation).

226 But see Anup Agrawal \& Charles R. Knoeber, Firm Performance and Mechanisms to Control Agency Problems Between Managers and Shareholders, 31 J. Fin. \& Quantitative Analysis 377 , 377 ( 1996) (stating that agency costs may be reduced through increased holding of shares by managers); Michael C. Jensen \& William H. Meckling, Theory of the Firm: Managerial Behavior, Agency Costs and Oronership Siructure, 3 J. Fin. Econ. 305, 312 (I976) (stating that agency problems arise the moment the manager owns less than roo percent of the corporation's stock).

227 See Jesse M. Fried, Share Repurchases, Equity Issuances, and the Optimal Design of Executive Pay, 89 Tex. L. Rev. I I 3 , I I 13 (20I I) ("The Purpose of equity compensation is to better align executives' interests with those of the firm's shareholders."); see also Jesse M. Fried \& Mira Ganor, Agency Costs of Venture Capitalist Control in Startups, 81 N.Y.U. L. Rev. 967, 1010 (2006) ("[E]quity compensation aligns the interests of employees with those of shareholders."); David F. Larcker \& Brian Tayan, Pledge (and Hedge) Allegiance to the Company, Closer LOOK SERIES, Oct. I I, 20 I0, CGRP-I I, at 1, http://www.gsb.stanford.edu/cgrp/research/documents/CGRP I I-HedgingandPledging.pdf ("Companies include equity in a compensation package to align the interests of management with those of shareholders. If the executive performs well, both shareholders and the executive will profit; if the executive performs poorly, s/ he will suffer financially along with shareholders. In this way, equity compensation is expected to encourage a focus on long-term value creation."); Francine J. Lipman, Incentive Stock Options and the Alternative Minimum Tax: The Worst of Times, 39 HARv. J. ON LEgIs. 337, 345 (2002) (quoting the Congressional position that giving an option to the "management of a business to have a proprietary interest in its successful operation [would] provide an important incentive to expand and improve the profit position of the companies involved." (alteration in original)). For a succinct exposition of this position, see Randall S. Thomas \& Kenneth J. Martin, The Effect of Shareholder Proposals on Executive Compensation, 67 U. CiN. L. Rev. 1021 , 103 I n.40 ( I999). 
reflection of the law of unintended consequences, the opposite has become the case. ${ }^{228}$ The suggested antidote is longer vesting periods and greater restrictions, including limits on ability of managers to hedge the risk of equity-based compensation. ${ }^{229}$

Another approach focuses on expanding fiduciary duties to require directors, outside the context of a takeover proposal, to act in the longterm best interest of the corporation and its shareholders. ${ }^{230}$ According to the proponent, this "proposal attempts to give effect to the long-

Thomas and Martin state the following:

[T]he conflict between managers and shareholders interests can be mitigated through the use of incentive compensation packages which align the incentives of managers with those of shareholders. Stock options can be used to provide managers with an equity interest in the corporation. As executives' level of stock ownership increases, they will bear a greater percentage of the costs of any deviations from the standard of profit maximization. In this situation, self-interest will lead managers to act in shareholders' best interests.

Id. See generally Patricia M. Dechow \& Richard G. Sloan, Executive Incentives and the Horizon Problem: An Empirical Investigation, 14 J. Accr. \& EcoN. 5I (1991) (analyzing CEO expenditures in final years in office); Michael C Jensen \& Kevin J. Murphy, Performance Pay and TopManagement Incentives, $98 \mathrm{~J}$. PoL. ECON. 225 (1990) (estimating CEO sensitivity to pay-performance based on the ratio of the increase in CEO pay to the increase in shareholder wealth); Kevin J. Murphy, Corporate Performance and Managerial Remuneration: An Empirical Analysis, 7 J. Acct. \& ECoN. 11,12 (1985) (analyzing "the relationship between firm performance and managerial pay ..." from empirical data).

228 See Brian Cadman \& Jayanthi Sunder, Investor Myopia and CEO Horizon Incentives 6 (Working Paper, 2009), available at http://papers.ssrn.com/sol3/papers.cfm?abstract_id=956601 (noting that equity compensation tied to short-term stock returns would lead to investment in short-term projects); see also Lipman, supra note 227, at 345 (discussing early skepticism about the ability of stock options to align management-shareholder interests and improve corporate profitability); James R. Repetti, The Misuse of Tax Incentives to Align Management-Shareholder Interests, 19 CARDOZO L. Rev. 697, 70 I-02 (1997) (raising doubts about whether compensation through stock options accomplishes the objective of aligning management's interests with the interests of shareholders). See generally Myeong-Hyeon Cho, Ownership Structure, Investment, and the Corporate Value: An Empirical Analysis, 47 J. Fin. EcoN. 103 (1998) (challenging the notion that compensating executives through stock grants will have a positive effect on investment decisions and consequently corporate value); Jeong-Bon $\mathrm{Kim}$ et al., CFOs versus CEOs: Equity Incentives and Crashes, IOI J. Fin. EcoN. 713 (20I I) (demonstrating empirically that option-based compensation can increase the risk of a stock price crash).

229 See, e.g., Sanjai Bhagat \& Roberta Romano, Reforming Executive Compensation: Focusing and Committing to the Long-Term, 26 YALE J. ON REG. 359, 36 I (2009) (recommending exclusive use of restricted stock as the form of equity-based compensation); Eli Ofek \& David Yermack, Taking Stock: Equin-Based Compensation and the Evolution of Managerial Oronership, 55 J. FiN. $1367,1369-70$ (2000) (discussing the practice of hedging the risk of equiry-based compensation by managers); Richard A. Posner, Are American CEOs Overpaid, and, If So, What If Anything Should Be Done About It?, 58 DuKE L.J. 1013, 1045-46 (2009) (considering restricted stock as severance pay); Steven C. Caywood, Note, Wasting the Corporate Waste Doctrine: How the Doctrine Can Provide a Viable Solution in Controlling Excessive Executive Compensation, 109 Mich. L. Rev. III, 127-28 \& n.107 (2010).

230 Nadelle Grossman, Turning a Short-Term Fling into a Long-Term Commitment: Board Duties in a New Era, 43 U. Mich. J.L. ReForm 905, 905 (2010). 
standing formulation of directors' fiduciary duties as being owed both to the corporation as well as its stockholders, while also implementing the policy of creating long-term profitability for the benefit of our economy and society."231

Efforts aimed at focusing managers on long-term management are worthwhile. Nevertheless, there are legitimate questions that arise with respect to favoring one group of shareholders over another or guaranteeing that managers will not succumb to the wrong form of shareholder pressure. Some of these questions may be resolved through a long-term shareholder framework as a part of the corporate legal structure. Accordingly, this article in Part VI below proposes a long-term shareholder primacy norm in corporate law and stakes the case for it.

\section{Long-Term Shareholder Primacy Norm}

A number of policy reforms in response to the recent financial crisis, including the $2008 \& 2009$ bailout legislation ${ }^{232}$ and the 2010 Dodd-Frank financial reform legislation, ${ }^{233}$ proceed on the reasoning that the recent financial crisis was precipitated by the short-term disposition of corporate executives. ${ }^{234}$ Accordingly, they contain provisions that limit managerial incentives (such as executive compensation reform) or empower shareholders (e.g. through proxy access) to constrain managerial ability to tend to the short-term. ${ }^{235}$ Critics argue that shareholder short-termism is also a major problem and, therefore, empowering shareholders without addressing their short-termist tendencies defeats the purpose of the latest reform initiatives. ${ }^{236}$

Further, it is uncertain how expansion of director fiduciary duties to prioritize the interest of long-term shareholders would operate without

23I Id. at 965. Professor Grossman's full proposal is as follows:

I propose that directors be required to make decisions primarily for the purpose
of advancing the long-term best interest of the corporation and its stockholders.
That means that every time the board is faced with a business decision, it would
need to consider how that would benefit the corporation and the stockholders in
the long-term, and make decisions that are aimed at achieving that objective...
. That would not mean that the board must shape corporate strategy such that a
corporation foregoes all opportunities to make current profits - but it would mean
that realizing on current profits could not undermine the corporation's ability to
generate profits in the future....

Id. at 960 .

232 Emergency Economic Stabilization Act of 2008, 12 U.S.C. \$§ 520I-6I (Supp. IV 201 I); American Reinvestment and Recovery Act of 2009, Pub. L. No. I I I-5, I 23 Stat. I 15.

233 Dodd-Frank Wall Street Reform and Consumer Protection Act, Pub. L. No. I I I203, 124 Stat. 1376 (2010).

234 Usha Rodrigues, Corporate Governance in an Age of Separation of Ownership from Ownership, 95 Minn. L. Rev. 1822, 1823, 1839 (2011).

235 Id at $1839-40$.

$236 \mathrm{Id}$. at $1824-25$. 
the recognition and internalization by corporations of a norm of long-term shareholder primacy. ${ }^{237}$ For instance the proposal on reformulated fiduciary duty to manage for the long term categorically states that "directors could, in compliance with this duty, consider the interests of short-term stockholders in making business decisions," but are not permitted "to place those short-term interests above, or even on par with, the interests of stockholders and other corporate constituents in sustained corporate profitability." ${ }^{38}$ This formulation presupposes a norm to manage for the long-term interests of stockholders (and the corporation); otherwise, it is hard to find a legal justification for preferring one group of shareholders (long-termists) over another (short-term oriented shareholders). ${ }^{239}$ The envisaged,norm is the "long-term shareholder primacy norm" discussed in greater detail below.

\section{A. The Case for Long-term Shareholder Primacy}

This article proposes a long-term shareholder primacy norm that is premised on the notion that managers should manage primarily and principally for the benefit of stockholders, but that it is in the best interest of the corporation, shareholders and other stakeholders for the corporation

237 See Matheson \& Olson, supra note 212, at 1376-77 (proposing legislation that would include a norm of long-term shareholder primacy).

238 Grossman, supra note 230 , at $96 \mathrm{I}$.

239 See Grossman, supra note 230, at 908 (advocating the imposition of a fiduciary duty on directors to act in the long-term best interest of the corporation and its shareholders; adding that "[w]hile some Delaware courts have expressed a preference for this type of long-term standard, they have generally not required it"); Walton, supra note 66, at 12 ("IT] he role of the corporation [is] to maximize the wealth of shareholders in the aggregate, rather than to maximize the wealth of long-term shareholders only, a policy position embraced by [some commentators] but one that is narrower than the current legal conception of the proper goal of corporations."); see, e.g., Lisa M. Fairfax, The Rhetoric of Corporate Law: The Impact of Stakeholder Rhetoric on Corporate Norms, 31 J. CoRP. L. 675, (2006). But see Henry Hansmann \& Reinier Kraakman, The End of History for Corporate Law, 89 GEO. L.J. 439, 439 (2001) (declaring that "there is no longer any serious competitor to the view that corporate law should principally strive to increase long-term shareholder value"); Bernard Black \& Reinier Kraakman, Delaware's Takeover Law: The Uncertain Search for Hidden Value, 96 Nw. U. L. Rev. 521 , 527 (2002) (discussing directors duty to maximize long-term shareholder value). Some commentators go further to reject the characterization of the corporation's goal as maximization of shareholder interests, even in the aggregate. According to Fairfax,

\footnotetext{
The rhetoric, however, does not reflect this flexibility. Amazingly, most corporate scholars continue to proclaim the dominance of the shareholder primacy theory despite these erosions. They have done so even after courts and legislatures clearly articulated increasingly stakeholder focused doctrines.

Less than five years ago, Professors Henry Hansmann and Reinier Kraakman proclaimed, "there is no longer any serious competitor to the view that corporate law should principally strive to increase long-term shareholder value." This proclamation in the face of an apparent shift in corporate law illuminates the unwavering nature of the shareholder primacy rhetoric in corporate legal discourse.
}

Id. at 690 (footnote omitted). 
to be run with a long-term perspective. ${ }^{240}$ The long-term shareholder primacy norm will focus on length of holding, but will also address shorttermist tendencies even by those shareholders that have long holding periods. ${ }^{241}$ Shareholders will continue to enjoy almost unfettered freedom to trade and maintain short holding periods, but their practices would no longer drive or dictate corporate policy.

The norm integrates the insights of shareholder primacists and director primacists who want the corporation managed with the maximization of shareholder value at the forefront $\mathrm{t}^{242}$ and other board primacists who are concerned that shareholder emphasis detracts from long-run growth because of deference to short-term shareholders to the detriment of all. ${ }^{243}$ The norm is also consistent with the argument, not necessarily based on any form of shareholder primacy, that management's pursuit of a longerterm strategy will benefit the shareholders and the corporation's other constituencies, whose prosperity is tied to the long-term prosperity of the enterprise's business operations. ${ }^{244}$ Managing the firm with a focus on shareholder value maximization in the long term will also address the question posed by communitarians and stakeholder theorists because a

240 See Fairfax, supra note 239, at 702 ("[P]roponents of the long-term view of shareholder primacy would contend that such a view accommodates non-shareholder issues. This accommodation occurs because 'stakeholder' concerns, such as giving money to charity or behaving responsibly towards employees and customers, inure to the benefit of shareholders in the long-term." (footnote omitted)).

241 See Bøhren, Priestley \& Ødegaard, supra note 3, at 1 n.1.

242 See Stephen M. Bainbridge, Director Primacy: The Means and Ends of Corporate Governance, 97 Nw. U. L. Rev. 547, 572 (2003) ("Director primacy does not deny that the proper "end" of corporate governance is shareholder wealth maximization. Director primacy does deny the logic of shareholder primacy - that the powers of the board of directors are delegated to the board by shareholders." (footnotes omitted)); Grant Hayden \& Matthew T. Bodie, Shareholder Democracy and the Curious Tum Toward Board Primacy, 5 I WM. \& MARY L. Rev. 2071, 2082-85 (2010) [hereinafter Hayden \& Bodie, Shareholder Democracy] ("Scholars have referred to the notion that corporations should seek primarily, if not solely, to maximize returns to their shareholders as the shareholder primacy norm or the shareholder wealth maximization norm. This norm is much more than a descriptive account of shareholders' rights; it is instead a normative judgment on the most socially efficient way of organizing the economy. Proponents of this norm argue that we will maximize our utility as a society only through a system of corporate law that recognizes and perpetuates shareholder primacy." (footnotes omitted)).

243 Lawrence Mitchell, Corporate Irresponsibility: America's Newest Export 3 (200I) (stating that the way to accomplish a corporate long-term focus "is, paradoxically, to free managers from the structural pressures of stockholders and capital markets ...."); John Haberstroh, Activist Institutional Investors, Shareholder Primacy, and the HP-Compaq Merger, 24 Hamline J. Pub. L. \& Pol'y 65, 95 (2002) (discussing the contention that empowering institutional investors is not the right approach to entrenching a long-term perspective in corporations); Lipton \& Rosenblum, supra note 54, at I 87-90 (decrying shareholder short-termism and advancing quinquennial election of directors as a way of freeing managers from managing for the short-term interests of shareholders); of. Hayden \& Bodie, Shareholder Democracy, supra note 242, at 2 I 16 (analyzing the long-term theorists shareholder primacy norm).

244 Lipton \& Rosenblum, supra note 54, at 227-28. 
corporation that does well in the long run will better protect the interests of all constituencies, including shareholders, employees, suppliers, customers and communities. ${ }^{245}$

While the norm of long-term shareholder primacy may be mandated by the courts and corporate statute, it may not necessarily take that course. $^{246}$ It may be accomplished through private ordering. ${ }^{247} \mathrm{~A}$ state

245 Jean Tirole provides a standard presentation of this question when he asks the following:

\begin{abstract}
To many people the economists' and legal scholars' sole focus on shareholder value appears incongruous. Managerial decisions do impact investors, but they also exert externalities on a number of "natural stakeholders" who have an innate relationship with the firm: employees, customers, suppliers, communities where the firm's plants are located, potential pollutees, and so forth. There is no denying that such externalities may be substantial; for example, the closure of a plant by a major employer in a depressed area has dramatic consequences for its workers and for the local economy. Why should institution design ignore the natural stakeholders, and favor the investors, who are "stakeholders by design," by giving them full control rights and by aligning managerial compensation with their interests?
\end{abstract}

Tirole, supra note 28 , at 3 . For a response that seems to confirm the view that the path to resolution is through a focus on the long-term shareholder, see Julian Velasco, The Fundamental Rights of the Shareholder, 40 U.C. Davis L. REv. 407 (2006). The social responsibility theory, according to Velasco,

\begin{abstract}
[M]anaged to persuade most people - in theory, at least-that the long-term perspective is the appropriate benchmark. Thus, concern about conflicting interests may be overstated; the conflict may not be as severe as often imagined and might be resolved betrer by a long-term approach to shareholder interests than by a paradigm of conflicting interests that need to be mediated.
\end{abstract}

Id. at 455 . For the counter-argument that stakeholder interests cannot be adequately protected under the current corporate form, see Rakhi I. Patel, Facilitating Stakeholder-Interest Maximization: Accommodating Beneficial Corporations in the Model Business Corporation Act, 23 ST. Thomas L. Rev. I 35 (2010). Patel instead argues for protection of the interests of shareholders and other stakeholders through a beneficial corporation. Id. at I37-39.

246 See Matheson \& Olson, supra note 212 , at $1376-77$ (proposing legislation to enable directors manage for the interest of the corporation and its long-term shareholders); see also Grant M. Hayden \& Matthew T. Bodie, The Uncorporation and the Unraveling of "Nexus of Contracts" Theory, I09 Mich. L. Rev. I I 27, 1135-37 (2011) (discussing the place of mandatory terms in corporate governance).

247 Lynn M. LoPucki \& Walter O. Weyrauch, A Theory of Legal Strategy, 49 DukE L.J. 1405, I43 I-32 (2000) (stating that "private ordering" is the economists' term for what sociologists refer to as social norms). For valuable discussions of the role of private ordering in corporate law, see Henry N. Butler \& Larry E. Ribstein, Opting Out of Fiduciary Duties: A Response to the Anti-Contractarians, 65 WASH. L. Rev. I (1990). Butler and Ribstein argue that "private parties to the corporate contract should be free to order their affairs in whatever manner they find appropriate." See generally Lucian A. Bebchuk \& Scott Hirst, Private Ordering and the Proxy Access Debate, 65 Bus. LAw. 329 (2010) (supporting shareholder ability to opt out of federal proxy access regime); Joseph A. Grundfest, The SEC's Proposed Proxy Access Rules: Politics, Economics, and the Law, 65 Bus. LAw. 361 (2010) (arguing that implementing an opt-out approach to proxy access would introduce the difficult problem of defining optimal proxy access default rule); Charles M. Nathan \& Paul F. Kukish, Conference Board, Private Ordering and Proxy Access Rules: The Case for Prompt Attention (2010), http://www.hedgerelations. com/articles/TCB\%2oDN.pdf (warning companies of the effect of the changes in the proxy access rules). 
corporate statute may establish some standards or guidelines on longterm shareholder primacy that corporations would be free to adopt. ${ }^{248}$ The statute may also impose such standards but allow corporations to opt-out of the arrangement. ${ }^{249} \mathrm{~A}$ pure form of private ordering may take the nature of a voluntary effort undertaken by individual corporations that assumes a stronger force as the practice becomes widespread. ${ }^{250}$ The management of a corporation may propose, at a general meeting of shareholders, the adoption of the norm as the guiding framework for corporate policy and decisionmaking. Shareholders may also initiate the effort through a shareholder resolution that, if adopted by a significant majority of shareholders, signals to the management the direction they want the company to take. ${ }^{251}$ Voluntary adoption and internalization of the norm may be a more effective way of ensuring the entrenchment of long horizon management. ${ }^{252}$ Private ordering will obviate unwanted wrangling among various interest groups. Besides, internalization of norms ensures high levels of compliance with those norms. ${ }^{253}$ Conversely, when actors have not internalized a particular norm, not even the law or the markets may succeed in constraining

248 The Matheson \& Olson proposal provides a useful template that may be adapted and adopted for this purpose. Matheson \& Olson, supra note 2 i 2, at 1376-77; see also Jeffrey $N$. Gordon, The Mandatory Structure of Corporate Law, 89 CoLum. L. Rev. I549, 1555 (1989) ("[W] here important changes in the relationship between shareholders and management are at issue, legislation that relaxes mandatory rules should always require an affirmative shareholder decision to 'opt in' to the change rather than merely permitting shareholders to 'opt out."').

249 See Lucian A. Bebchuk \& Robert J. Jackson, Jr., Corporate Political Speech: Who Decides?, 124 HARv. L. Rev. 83, 102-04 (2010) (advocating a similar approach in the context of decisions regarding corporate political speech).

250 See Christine Horne, Sociological Perspectives on the Emergence of Norms, in Social Norms 3, 6 (Michael Hechter \& Karl-Dieter Opp eds. 2001) ("Whatever the reason for the initial action, when many people engage in the same behavior, that behavior comes to be associated with a sense of ougheness.").

25 I For a comparative analysis of private ordering and a mandatory approach, see Strine, Governance Question, supra note 16, at 2 I. Strine argues that "to be consistent with the private ordering approach that has served to create so much wealth from the corporate form, stockholder input ... should proceed only if the stockholders of a particular corporation have decided that such input is good for their specific corporation. Private ordering will avoid the costs of an overbroad and rigid mandate, and allow the marketplace to innovate and develop approaches that, with experience, move toward the right balance." Id. at 2 I (footnote omitred).

252 See Brendan S. Maher, The Civil Judicial Subsidy, 85 IND. L.J. 1527, 1539 (2010) ("Society is lubricated by trust and internalized norms of conduct ....").

253 See, e.g., Robert C. Ellickson, Order Without Law: How Neighrors Settle DisPUTES 4-5 (1991) (arguing that social norms can displace state-made law); Robert Cooter, Do Good Laws Make Good Citizens? An Economic Analysis of Internalized Norms, 86 VA. L. Rev. 1577, I591 (2000) (stating that the effectiveness of laws is partly determined by the internalized values of good citizens); Richard A. Falk, Book Review, 104 AM. J. INT'L L. 543, 547 (2010) (reviewing INTERnATIONAL LAW AND Its OTHERs, (Anne Orford ed. 2006) (stating that high levels of compliance with societal norms is a function of the internalization of those norms); LoPucki \& Weyrauch, supra note 247 , at 1435 (arguing that social norms have greater effectiveness than written laws). 
their behavior. ${ }^{254}$ In addition, norms can eventually graduate into legal stipulations. ${ }^{255}$ An aspirational norm, though not mandatory by definition, can serve as a potent guide for reasonable and acceptable director decisionmaking outcomes. ${ }^{256}$

A strong case for the long-term shareholder primacy norm can be made on the basis that long-term shareholders face greater vulnerabilities than other shareholders and corporate constituents. ${ }^{257}$ In addition, longterm shareholder primacy better suits the rationale for shareholder empowerment, namely that "shareholders, as the residual claimants, will maximize long-term firm value because they are last in line at the time of liquidation, and thus have strong reasons to guard against near term collapse." 258 Further justification emanates from the point that this idea is favorable ${ }^{259}$ or should be amenable to virtually everyone in the corporate sphere, including the most ardent short-termist, who would need a general investor understanding that today's share price reflects long-term value to

254 Melanie B. Leslie, Helping Nonprofits Police Themselves: What Trust Law Can Teach Us About Conflicts of Interest, 85 CHI.-KENT L. REv. 55 I, 56I (2010) ("[W]hen dominant directors have not internalized those norms [regarding conflicted transactions], neither law nor markets play a meaningful role in preventing self-interested behavior.").

255 Robert Axelrod, An Evolutionary Approach to Norms, 80 Am. PoL. Sci. Rev. I095, 106 (1986) ("Norms often precede laws but are then supported, maintained, and extended by laws."); Iskra Uzunova, Note, Roma Integration in Europe: Why Minority Rights Are Failing, 27 ARIZ. J. INT'L \& COMP. L. 283, 307 (2010) ("The interaction between legal and social norms is complex: they are interdependent but may arise independently of each other and may affect each other's formation."); Marc. T. Moore, Private Ordering and Public Policy: The Paradoxical Foundations of Corporate Contractarianism 6-9 (Working Paper, 2010), available at http://papers. ssrn.com/sol3/papers.cfm?abstract_id=1706045 (discussing the role of private ordering in the evolution of corporate law).

256 Jeffrey M. Cunningham, Boardroom Justice, NACD DiRectorship, Dec. 17, 20I0, http:/www.directorship.com/boardroom-justice/. In an interview, Delaware Chancellor, William B. Chandler III, responded as follows:

\footnotetext{
What I was hoping to say in [the] Disney [case] is merely that it's highly unlikely that they would ever be found liable if directors followed a path of best practices You could look at these best practices similar to a safe harbor provision. But best practices in any endeavor constitutes an aspirational norm rather than a requirement, which hopefully will inspire as well as guide and inform directors in their decision-making.
}

Id.

257 See Walton, supra note 66, at i I n.5 (stating that one revelation from the recent financial crisis was that while short-term investors and executives profited handsomely from the housing bubble, long-term investors saw the evisceration of their investments); see also Margaret M. Blair \& Lynn A. Stout, A Team Production Theory of Corporate Law, 85 VA. L. Rev. 247, 314 ( 1999) (discussing shareholder vulnerability generally).

258 Rodrigues, supra note 234 , at 1829.

259 Kelli A. Alces, The Equity Trustee, 42 ARIz. ST. L.J. 717, 731 (2010) (noting that "[d] espite many parties' interests in short-term profits, long-term wealth maximization should remain the goal of corporate governance" because it is in the interest of the various parties involved in the corporate enterprise). 
be able to profitably engage in her investing style. ${ }^{260}$ Indeed, indications already abound that "the corporate rhetoric can be viewed as expressing a normative preference for long-term shareholder primacy." 261 The next logical step is to back the "rhetoric" with action.

One way of backing the rhetoric with action will be the introduction of a cadre of shareholders who enter into an enforceable commitment to hold stock for an ascertainable, lengthy period of time. ${ }^{262}$ Moving in that direction is likely to supplement and energize the norm. In the early 1990 s, Michael Porter made the case for addressing short-termism through certain structural changes. ${ }^{263}$ Porter argued that a formula for discouraging shortterm trading and encouraging long-term holding is for corporations to have the creation of long-term shareholder value as their stated mission. ${ }^{264}$ Firms would be encouraged to seek out long-term shareholders and accept their role in governance. ${ }^{265}$ The cadre of legally-committed long-term shareholders will provide a practical application of this call.

\section{B. Potential Objections to Long-term Shareholder Primacy}

Usha Rodrigues has identified some objections to privileging longterm shareholders that are germane to this article's proposal. ${ }^{266}$ Opponents

260 Repetti, Tax Incentives, supra note 159, at 71 3-14; see also Black, Watching Agents, supra note 24 , at 863 ("[E]ven an investor who plans to sell next month must care about long-term value, because buyers will have a longer horizon."); Ira M. Millstein et al., Ten Thoughts For Ordering Governance Relationships in 2010, in Eight Annual Director's Instirute on CoRporate Governance, at 341, 344 (PLI Corp. L. \& Practice, Course Handbook Sèr. 20 o o) ("Strong corporate performance over the long-term benefits everyone - shareholders, boards, managers, creditors, customers, suppliers, employees and the public. But some investors focus instead on short-term stock price performance, which can lead to high-risk strategies that are unsustainable and could encourage perverse incentives that put a company's future at risk.").

261 Fairfax, supra note 239 , at 702.

262 I develop this idea more fully in a separate article that proposes the creation of a form of relatively illiquid. securities held by committed long-term shareholders under a revised trust fund theory. See generally Emeka Duruigbo, Stimulating Long-Term Shareholding (Working Paper, 2001 ), available at http://papers.ssrn.com/sol3/papers.cfm?abstract_id=1939502. Shareholders that make such commitment would receive significant roles in corporate policy-setting and decision-making. As one prominent board primacist has observed, notwithstanding the fact that "shareholders may be able to liquidate their investments quickly, those who choose to invest for the long-term are surely deserving of management consideration." Lipton, Finance Corporatism, supra note 149 , at 36 . If long-term holders of shares that retain their liquidity deserve such consideration, certainly a stronger case can be made for those that voluntarily agree to make their shares illiquid for a given period of time. Duruigbo, supra, at 19-22.

263 See James P. Hawley \& Andrew T. Williams, The Rise of Fiduciary Capitalism: How Institutional Investors Can Make Corporate America More Democratic i6i (2000).

264 Id.

265 Id.

266 Rodrigues, supra note 234, at 1825-26. 
may object to the proposal herein because it proceeds on the basis that we still have long-term shareholders. On the contrary, there is a legitimate question about the existence of long-term investors in today's investment firmament. Some people that invest for the long-term may be properly characterized as "short-term investors with long-term interests." 267 Achieving these investors' long-term goals does not necessarily preclude short-horizon investing. In fact, such investors may prefer a series of short-term investments that yield higher returns cumulatively than single investments that are held for longer periods of time but generate lower returns. If that is the case, focusing on the long-term investor's interest clearly misses the point. ${ }^{268}$ Assuming, but not necessarily conceding, that long-term investors are an extinct species, it is still important to note that encouraging long-term investing is a worthwhile goal because it benefits the society and economy to have firms that are run for the long-term. ${ }^{269}$ Long-term investors are more likely to enable long-term management. ${ }^{270}$ Thus, maintaining an environment in which such investors thrive is a commendable goal.

Even if the existence of the long-term shareholder is accepted, additional scholarly objection to a heightened protection of long-term shareholders exists. ${ }^{271}$ The basis of this objection is that an efficient capital market already provides sufficient protection for this type of shareholder through a higher rate of return on the risk they assume in holding stocks for a longer duration. ${ }^{272}$ However, this objection suffers from its assumption that the market in which the long-term shareholder operates is totally efficient. ${ }^{273}$ This assumption has been strongly disputed. ${ }^{274}$ Instead, a counter-contention can be made that "at least sometimes market prices reflect short-term interests, rather than the long-term value of the firm, and that the market does not fully price in systemic risk." 275 In other words, long-term investing exposes long-term shareholders to certain vulnerabilities that place them in a unique position to warrant greater

267 Id. at 1826.

268 See id.

$269 \mathrm{Id}$. ("It is in everyone's best interest for firms to be run for the long term. Stable firms create stable employment, wealth, and goodwill that short-lived companies cannot provide. The question our society faces is how to encourage long-lived firms when individual players, including even long-horizoned investors, may be looking for a quick payoff.").

270 See, e.g., Summers \& Summers, supra note 93, at 272-73 (advancing the argument that encouraging long-term investment would in turn encourage long-term management); Strine, Governance Question, supra note 16, at 8-9.

271 See Rodrigues, supra note 234 , at 1825.

$272 I d$.

273 Id. at $1825-26$.

274 See supra notes $64-66$ and accompanying text.

275 Rodrigues, supra note 234 , at 1826 . 
protection. ${ }^{276}$ As mentioned in the immediately preceding section, the recent financial crisis presents a fitting illustration and telling confirmation of this situation. While short-term investors profited handsomely, many long-term investors were wiped out. ${ }^{277}$

One problem identified by opponents of shareholder empowerment is that it may end up privileging one group of investors - short-term investors who are more likely use the new powers - to the disadvantage of the rest of the investor community. ${ }^{278} \mathrm{~A}$ converse argument may be made that this article's proposal confers a privilege on long-term investors as a group to the detriment of short-term investors. This objection has some merit. Indeed, a similar criticism has trailed the corporate reforms that were included in the bailout package provided by the U.S. government to certain corporations, beginning in $2008 .{ }^{279}$ The decision to give long-term investors the edge is a conscious one premised on the conclusion that it is in the best interests of all investors, the firm, economy, and society to encourage long-term investing. Thus, the reasoning behind objecting to privileging short-term investors, notably that such investors are about the only ones that benefit to the injury of all other interests, is not applicable to confining and consigning that privilege to long-term investors. ${ }^{280} \mathrm{On}$ the other hand, the case for long-term shareholder primacy is bolstered by the absence of the dangers inherent in short-term shareholder empowerment and the rationale for shareholder empowerment generally, which is that

276 See supra note 257 and accompanying text.

277 Id.

278 See Rodrigues, supra note 234 , at 1829.

279 Rodrigues' response to this criticism is as follows:

The first [criticism] is that the bailout reforms are ill-advised because they seek to maximize the long-term wealth of a corporation; according to some critics, any shareholder-focused agency model should encourage management to maximize the corporation's short-term stock price. This view, however, is in tension with several principles of corporate law. The shareholder-wealth-maximization norm gives managers a great deal of leeway in how they go about their maximizing, and the pursuit of short-term price appreciation is clearly not required. It is true ... that short-term stock prices are more reliable today than in the past as a measure of management's performance. But that observation is largely beside the point. There is ample room in the shareholder-wealth-maximization norm to privilege long-term over short-term wealth maximization, as the governmental response to the bailout seeks to do.

Id. at $1846-47$ (footnotes omitted).

280. Cf. Iman Anabtawi, Some Skepticism About Increasing Shareholder Power, 53 UCLA L. REv. 56I , $581-83$ (2006); (discussing dangers of empowering short-term investors); Rodrigues, supra note 234, at 1829 (stating that there are occasions "where the short-term gain comes at the expense of the corporation over time"). But of. Stephen M. Bainbridge, Director Primacy and Shareholder Disempowerment, I 9 HARv. L. REv. 1735, 1744-5 I (2006) (explaining why limited voting rights of shareholders is the majoritarian default for corporation law). 
being residual claimants, shareholders are motivated to promote long-term value.

Corporate law frowns upon the imposition of constraints on the discretion of directors to manage the corporation as they deem fit. ${ }^{281}$ One of the admirable aspects of the shareholder-wealth-maximization norm is that it "gives managers a great deal of leeway in how they go about their maximizing" thus enabling them to favor long and short term interests based on the circumstance. ${ }^{282} \mathrm{~A}$ long-term shareholder primacy norm impinges on this discretion and mandates managers to be devoted instead to long-term shareholder-wealth-maximization. One response to this criticism is that recent corporate developments suggest that managerial freedom to emphasize both the long and short term as the need arises has been severely curtailed by a besieging army of activist short-term investors, who push managers to take actions with a near-term focus such as selling a division or leveraging the firm to declare huge dividends to the immediate benefit of the short-term investors and ultimate detriment of the company. ${ }^{283}$ More importantly, a long-term shareholder primacy norm is not adamantly opposed to short-term considerations, only those considerations that would injure the health of the corporation. In such situations, the management would be empowered to disregard such nearterm proposals, without risking any unsavory consequences from activist short-termists.

\section{CONCLUSION}

Active short-term trading in stocks, as opposed to diligent long-term investing, is once again a topical issue. ${ }^{284}$ Short-termism is believed to

281 Restriction of director's discretion is, generally, occurs only in narrow circumstances. E.g., Galler v. Galler, 203 N.E.2d 577, 581 (Ill. 1964) (holding that invasion of the powers of the directorate is acceptable in the "absence of an objecting minority interest, together with the absence of public detriment"); Clark v. Dodge, I99 N.E. 641, 642 (N.Y. 1936) (holding that a slight impingement on the discretion of directors is permissible, especially if no harm is occasioned thereby); McQuade v. Stoneham, i 89 N.E. 234, 237 (N.Y. 1934) (holding that a shareholder agreement that precludes the board of directors from changing officers, salaries, or policies except by consent of the contracting parties is illegal); see also MODEL Bus. CoRP. ACT $\$ 8.01$ (2007) ("All corporate powers shall be exercised by or under the authority of the board of directors of the corporation...."); DeL. CODE ANN. tit. 8, § I 4 I (200I) ("The business and affairs of every corporation organizes under this chapter shall be managed by or under the direction of a board of directors ....").

282 Rodrigues, supra note 234 , at 1847.

283 Id. at I 833-34; Anabtawi \& Stout, supra note 64, at $129 \mathrm{I}-92$ (discussing short-term investor activism to the advantage of these shareholders and the detriment of the corporation and its other constituents).

284 See Kelly \& White, supra note 12, at 775 (stating that short-termism "is gaining currency in business circles"); see also Carolyn Brancato \& Michael Price, The Institutional Investor's Goals for Corporate Law in the Twenty-First Century, 25 DEL. J. CoRP. L. 35, 44 (2000) 
influence corporate policy. because managers bow to perceived pressure from transient investors. Moreover, shareholders are quick to dispose of their stock, instead of staying and demanding change in corporate direction. The result is a corporate world that is fixated on quarterly earnings statements and not sufficient devotion to generating long-term value. ${ }^{285}$ This article has examined the short term - long term debate and evaluated three proposals advanced to address the short-termism question, namely securities transaction tax, capital gains tax reform, and loyalty dividends. It notes that their limitations propel a consideration of an alternative regime that integrates managerial short-termism into the equation. It is imperative to free managers from both their independent myopia and shareholder pressure that engenders managerial myopia through the adoption of a norm of long term shareholder primacy. Under this norm, managers will perform their functions with a primary focus on long-run growth of the corporation and what is in the interest of long-term shareholders. Accordingly, they will be able to use the legal shield provided by the norm to ignore the pressure of those shareholders that are only concerned with short-term profit.

Some remarkable reactions to the Enron debacle and the recent global financial crisis locate the cause and solution to the problem in the shareholder. Short-term oriented shareholders are believed to have driven corporate managers to decisions that led to the catastrophes. ${ }^{286}$ Yet, some scholars also attribute the problem to a lack of shareholder power. ${ }^{287}$ Although both responses are disputed, ${ }^{288}$ one can find some grain of truth in each of them. This work has extensively discussed the influence a shortterm investor orientation can have on managers. Overcoming managerial myopia may require shareholder empowerment. However, the focus of this empowerment should be on shareholders that clearly demonstrate a long-term orientation. This article has argued that a long-term shareholder primacy norm will provide this sort of empowerment. The long-term shareholder primacy norm would provide a framework within which to address difficult questions relating to the appropriate management of the corporation to the benefit of its constituents. While this norm may be

("No issue continues to polarize corporations and institutional investors more than 'shorttermism' - the notion that institutional investors are only speculators or traders ....").

285 See David Millon, Why is Corporate Management Obsessed with Quarterly Earnings and What Should Be Done About It?, 70 Geo. WASH. L. Rev. 890, 890 (2002) ("What is lost is a more patient approach to management emphasizing the long-term well being of the corporation and all its stakeholders. Sacrificed are potentially more lucrative payoffs that require immediate expenditures but yield their fruits only over the long haul.").

286 Hill, Unpredictable Shareholder, supra note 81, at 10 I 2-14.

287 Id. at roi 2 .

$288 \mathrm{Id}$. at 1012-14. 
initiated by legislative action or judicial fiat, it may also evolve through private ordering. 